\title{
The Sanction for Violation of California's One-Action Rule
}

\author{
Darren Conley†
}

In California when a debtor defaults on a real property secured debt, the creditor's options are significantly limited by section 726(a) of the California Code of Civil Procedure. Commonly referred to as the one-action rule, section 726(a) most obviously aims to prevent a real property secured creditor from suing the defaulting debtor on the indebtedness itself prior to foreclosing on the security interest. If the debtor in the situation described does not raise the one-action rule as an affirmative defense and if the creditor obtains a personal judgment on the debt, the one-action rule would forever bar the creditor from foreclosing on the security interest. But what effect does the one-action rule have when a creditor that holds three crosscollateralized, real property secured promissory notes representing a single debt judicially forecloses on the first two mortgages, omitting reference of the third security interest and the note that it secures from the petition for foreclosure? And what happens when a bank, acting as mortgagee, seizes the unencumbered funds of a defaulting mortgagor/depositor prior to foreclosing on the real property security interest? This Comment addresses these less-obvious applications of the one-action rule, providing a definite answer to the first type of problem and a proposal for dealing with the second.

\section{INTRODUCTION}

Prior to 1860 a inortgagee in California, upon the default of a mortgagor, was entitled to bring an action on the note as well as an action to foreclose the real property security imterest, which could be maintained mdependently of or concurrently with the action on the note. ${ }^{1}$ In 1860

$\dagger$ B.A. 1988, University of California, Davis; J.D. candidate 1992, Boalt Hall School of Law, University of California, Berkeley. I am grateful to Professor John R. Hetland, Professor Charles Hansen, and Jim O'Brien for their efforts and advice.

1. Felton v. West, 102 Cal. 266, 269, 36 P. 676, 677 (1894); see also Comment, Mortgages and Trust Deeds: Enforcement of a Secured Debt in California, 31 CALIF. L. REv. 429, 430 n.8, 431 n.9 (1943) (describing alternative actions available at common law to California nuortgagees) (authored by Aldo P. Guidotti).

The one-action rule is addressed to real property secured transactions. However, throughout this Comnient, for simplicity's sake, the tern "nuortgagor" is used niterchangeably with "debtor," and the tern "nuortgagee" with "creditor." 
the legislature enacted California's one-action rule ${ }^{2}$ in response to concerns that mortgagors would be burdened by the multiplicity of actions available to creditors under the prevailing laws. ${ }^{3}$ Section $726(a)$ of the California Code of Civil Procedure (the one-action rule) provides, in pertinent part: "There can be but one form of action for the recovery of any debt or the enforcement of any right secured by mortgage upon real property . . . , which action sliall be in accordance with the provisions of this chapter."

The effect of the one-action rule is to require a creditor seeking to recover on a debt to judicially foreclose on all security for that debt, ${ }^{5}$ to sue for the entire debt, ${ }^{6}$ and to obtain a personal deficiency judgment

2. See Comment, supra note 1 , at 429 ("The 'one action rule' first appeared in California by an amendment made in 1860 to section 246 of the Civil Practice Act.").

3. "The express purpose of section 905 of the proposed New York Code of Civil Procedure of 1850, from which section 726 was derived, was stated to be 'to prevent a multiplicity of actions.'" Id. at 430 (quoting proposed N.Y. CODE CIV. Pro. $\$ 905$ note at 385 (1850)); see R. BERnHARDT, California Mortgage and Deed of Trust Practice § 4.4, at 187 (2d ed. 1990); infra notes 24-26 and accompanying text.

4. Cal. Civ. Proc. Code $\S 726$ (a) (West 1991).

The creditor's one action must be in accordance with the creditor's statutory remedy of judicial foreclosure. Id. $\$ \S 725 \mathrm{a}-730$. For a legislative history regarding foreclosure as the only proper action under $\$ 726$, see Comment, Mortgages: Where a Book Account Becomes Secured by a Note and Mortgage the Creditor Must Foreclose, 11 CALIF. L. REv. 195, 196 n.3 (1923) (authored by T.H. Louttit).

In 1933 the one-action provision was amended to its present form limiting the creditor to "one form of action," in contrast to "one action" as was previously provided. However, the courts have consistently read the statute as limiting the creditor to one action, despite the amendment. See $\mathbf{R}$. BernhardT, supra note $3, \S 4.3$, at 186-87; California Real Property Financing $\S 3.41$, at 198-99 (G. Graham ed. 1989) (umiversally accepted interpretation of the statute, that the creditor is limited to a single action, "is consistent with the [statute's underlying] policy of limiting multiplicity of lawsuits"); J. HeTLAND, CALIFORNIA REAI EsTATE SECuRED TRANSACTIONS $\$ 6.18$, at 258-59 (1970) (citing numerous cases to demonstrate that courts have ignored the amendment); $4 \mathrm{H}$. Miller \& M. Starr, Current Law of California Real Estate § 9:113, at 374 n.73 (2d ed. 1989) ("[C]ases subsequent to the amendment have [ignored] the statutory change."); see also Comment, Mortgages and Trust Deeds: Foreclosure Sale of a Portion of the Mortgaged Premises, 25 CALIF. L. REv. 469, 470 (1937) (authored by Charles L. Heininings) ("Very probably the legislative intent was only to define a kind of action."). If the statute were interpreted literally so as to merely limit the creditor to one form of action, it could be argued that the amendment was intended to permit successive foreclosure actions on separate parcels of property to collect a singlc debt. $4 \mathrm{H}$. MILLER \& M. STARR, supra $\S 9: 113$, at 374 n.73.

Although the statute refers only to mortgages, it applies equally to deeds of trust, Bank of Italy Nat'1 Trust \& Sav. Ass'n v. Bentley, 217 Cal. 644, 658, 20 P.2d 940, 945, cert. denied, 290 U.S. 659 (1933), and to equitable mortgages, James v. P.C.S. Ginning Co., $276 \mathrm{Cal}$. App. 2d 19, 22, 80 Cal. Rptr. 457, 459 (1969).

5. See 4 H. MILlER \& M. STARR, supra note 4, § 9:104, at 343 \& n.39 (citing numerous cases in support of this common understanding of the rule's operation).

6. See Hetland \& Hansen, The "Mixed-Collateral" Amendments to California's Commercial Code-Covert Repeal of California's Real Property Foreclosure and Antideficiency Provisions or Exercise in Futility?, 75 CALIF. L. REV. 185, $205-06$ (1987) ("The effect of obtaining a judgment for less than the entire debt-whether or not any part of the security has been foreclosed in the same action-is a waiver of the balance of the debt, i.e., a waiver of that part of the obligation not recovered in the single action." Id. at 206.). 
against the debtor, if available, all in the same judicial foreclosure action. $^{7}$ The rule has at least two important imphications. First, a creditor may not waive a security interest in real property by obtaining a personal inoney judgment on a debt prior to foreclosing on all security for that debt. ${ }^{8}$ The creditor is prohibited from circumventing the one-action rule in this manner because "[t]he hability of the mortgagor is . . . contingent on the fact that a sale of the mortgaged premises shall fail to satisfy the debt and costs." In other words, a creditor must first bring an action on and exhaust the inortgaged security before recovering from the debtor personally. Second, if the creditor does not follow this procedure, for example by bringing an action directly on the note, or by foreclosing on less than all of the security in an action for judicial foreclosure, the creditor inay be subject to a sanction for violatimg the one-action rule. ${ }^{10}$

While commentators generally agree that a violation of the oneaction rule should be sanctioned, the proper scope of that sanction is vigorously debated. Numerous commentators and practitioners adopt the view that the sanction for violation of the one-action rule should be loss of the creditor's rights in the security only and should never include loss of the underlying debt. ${ }^{11}$ Others, however, advocate the view that

7. See 4 H. MILLER \& M. STARR, supra note 4, \$ 9:104, at 344 ("[T] he creditor must exhaust the secnrity by foreclosure proceedings, and he can only recover a personal judgment against the [debtor] by obtaining a deficiency judgment after a judicial foreclosure sale.").

8. Barbieri v. Ramelli, 84 Cal. 154, 156-57, 23 P. 1086, 1087 (1890).

9. Biddel v. Brizzolara, 64 Cal. 354, 362, 30 P. 609, 612 (1883).

10. The creditor will only be sanctioned if the debtor fails to compel the creditor to include all security in the creditor's initial action. See infra text accoinpanying notes 50-75.

11. Professor Cynthia Mertens and Dennis Amold are among coininentators and practitioners who follow the view that the sanction for violation of the one-action rule is loss of the creditor's rights in the security only. Professor Mertens states that "there is no justification" for the loss of the debt in addition to the loss of the security when imposing the one-action rule sanction. Mertens, California's Foreclosure Statutes: Some Proposals for Reform, 26 SANTA ClARA L. REV. 533, 554 n.102 (1986); see also Rowan \& Mertens, Bank of America v. Daily: Setoff versus the Right To Foreclose, 8 REAL PROP. L. REP. 73, 78 (1985) ("A debtor should not . . . be doubly sanctioned for violating CCP $\$ 726 . ")$.

Amold refers to the loss-of-security and loss-of-debt sanction as an "unduly formalistic turu-ofthe-century judicial rationale" involving "rather circular reasoning." Annold, Anti-Deficiency in the Eighties: The "Sanction Aspect," Fair Value and Where the Action Is (And Isn't), Cal. REAL Prop. J., Spring 1987, at 1,3. Aecording to Arnold, the scope of the sanction question "renains a major controversy under C.C.P. section 726." Hirsch, Annold, Rabin \& Sigman, The U.C.C. Mixed Collateral Statute-Has Paradise Really Been Lost?, 36 UCLA L. REV. 1, 46 (1988) [hereinafter Hirsch].

Professor Edward Rabin argues that in the context of an improper banker's setoff, the conibined loss-of-security and loss-of-debt sanction is unfair and has no basis in precedent, see Munoz \& Rabin, The Sequel to Bank of America v. Daily: Security Pac. Nat'l Bank v. Wozab, 12 REAL Prop. L. REP. 204, 209-10 (1989), while Edward Weiner suggests that early cases holding that the oneaction rule sanction may include loss of the debt appear to have been overruled by inore recent case law, see Weiner \& Tramz, New Breadth to Sanctions Against Foreclosing Secured Creditors, CAL. REAL Prop. J., Sunımer 1985, at 1, 2-3. Interestingly, Witkin, arguably the most proninent authority on California law, fails to even mention the possibility that the sanction for violating the 
the sanction, under certain circumstances, should include loss of that portion of the debt not reduced to judgment in the creditor's one action in addition to loss of the security. ${ }^{12}$

In this Comment I address the appropriate sanction for violation of the one-action rule im a variety of contexts, focusing on the situation in which a bank, acting as mortgagee, improperly sets off a debtor's unencumbered bank account prior to foreclosing on the property securing the debt. ${ }^{13}$ The question is a controversial one. In 1984 the California Court of Appeal, in Bank of America v. Daily, ${ }^{14}$ held that the sanction to be imposed on the creditor in such a situation was loss of the creditor's rights in the security. ${ }^{15}$ Furthermore, the court's disposition of the case effectively rendered the underlying obligation unenforceable, thereby

one-action rule might include waiver of the underlying debt. See 3 B. WITKIN, SUMMARY of CALIFORNIA LAW § 119, at 620-24 (9th ed. 1987).

12. Commentators and practitioners supporting the view that the sanction for the violation of the one-action rule may, under certain circumstances, include loss of that portion of the debt not reduced to judgment in the creditor's one action, as well as loss of the security, include Professor John Hetland, Professor David Leipziger, and Jumes Stillman.

Professor Hetland's 1970 treatise on real estate secured transactions is the cornerstone for the argument that the sanction for violation of the one-action rule is loss of both the security and the underlying debt. Hetland stated:

The classic sanction against the creditor who fails to exhaust all his security for the same debt in a single action is harsh, yet it follows inescapably from the availability of but one action to the creditor-he waives the balance of the security and he waives any claim to the unpaid balance of the debt.

J. HeTland, supra note $4, \S 6.18$ at 258 (citations omitted); see also Hetland \& Hansen, supra note 6, at 205-06 (sanction triggered "when a creditor proceeds to take a judgment or its equivalent for less than the full ainount of the debt, particularly when he compounds the error by failing to include all his security in the same foreclosure action") (footnote omitted).

Like Hetland, Professor Leipziger argues that when a foreclosing mortgagee holds several notes for a single debt and fails to sue on all of the notes and foreclose on all of the security in a single action, the proper sanction is loss of the unforeclosed-on security and loss of that portion of the debt not reduced to judgment. See Leipziger, Deficiency Judgments in California: The Supreme Court Tries Again, 22 UCLA L. REV. 753, 789 n.104 (1975).

Jaines Stillman, a respected expert on California real estate law, describes the "full sanction effect of the one-action rule" in eloquent terms:

[I] the borrower elects not to raise the rule defensively before the creditor's offending collection effort against general assets, the sanction provides that the mortgage is automatically exonerated. Worse yet, from the creditor's point of view, it has long becn argued, and courts have uniformly accepted, that the exoneration extends to the collectibihty of any remaining portion of the debt not reduced to judgment at the time the sanction arises. Accordingly, both the mortgage and the remaining debt become valueless. Stillman, Helping Those Who Help Themselves: The Banker's Offset in California After Security Pacific National Bank v. Wozab, Banking L. REV., Spring 1991, at 8, 9.

Miller and Starr's treatise repeatedly states that the sanction for violation of the one-action rule is loss of the security, but also recognizes the controversy by noting that "[t]here is some indication that the sanction may be inore severe" in certain situations. 4 H. MiLLER \& M. STARR, supra note $4, \S 9: 111$ at 359 .

13. The term "improper banker's setoff" is used in this Comment when referring to this situation.

14. 152 Cal. App. 3d 767, 199 Cal. Rptr. 557 (1984).

15. Id. at $773,199 \mathrm{Cal}$. Rptr. at 560. 
completely releasing the debtor from liability on the debt. ${ }^{16}$ In 1989 the California Court of Appeal, in Security Pacific National Bank v. Wozab, ${ }^{17}$ followed the Daily court's sanction analysis even though the improper setoff involved roughly $\$ 2800$, while the debt forfeited as a result of the sanction imposed amounted to over $\$ 976,000 .^{18}$ In November, 1990, the Supreine Court of California reversed the appellate court, ${ }^{19}$ effectively holding that the proper sanction to be imposed was loss of the security only, ${ }^{20}$ thereby reducing the status of the bank to an unsecured creditor but preserving its ability to pursue the underlying debt.

The supreme court's disposition of Wozab has not ended the scopeof-the-sanction controversy in the context of improper banker's setoffs. The main question before the court in Wozab was whetler the appropriate section 726 sanction for an improper banker's setoff should be loss of the security or loss of both the security and the underlying debt. ${ }^{21}$ Faced with extraordimary facts and a controversial doctrine that was virtually inapplicable to the transaction at issue, the supreine court deepened the sanction controversy by suggesting that each of the sanctions lias its place in one-action rule doctrine. ${ }^{22}$

In Part I of this Comment I discuss the policy justifications that serve as the driving force behind section 726 sanction cases. Part II describes the inechanics and application of the one-action rule as defined by the statute itself and by cases interpreting the statute. Part III provides an in-deptli analysis of the scope of the sanction, including the persuasive rationales, cases, and commentary in support of eacli side of the controversy. Part IV addresses the sanction controversy in the specific context of improper banker's setoff cases. Part V analyzes the Wozab opinion, concluding that the California Supreme Court's careless application of the one-action rule undermined its goal of resolving the sanction controversy. Finally, Part VI presents a proposal for a uniformly apphcable sanction in the context of improper banker's setoffs.

16. See id. at 771, 774, 199 Cal. Rptr. at 558, 560; infra note 137.

17. 223 Cal. App. 3d 1042, 258 Cal. Rptr. 850 (1989), rev'd, 51 Cal. 3d 991, 800 P.2d 557, 275 Cal. Rptr. 201 (1990).

18. Id. at 1056-57, $258 \mathrm{Cal}$. Rptr. at 858 .

19. Security Pac. Nat'1 Bank v. Wozab, 51 Cal. 3d 991, 1006, 800 P.2d 557, 566, 275 Cal. Rptr. 201, 210 (1990).

20. See id. at 1001-02, 1004, 800 P.2d at 563, 565, 275 Cal. Rptr. at 207, 209; infra note 136.

21. See Wozab, 51 Cal. 3d at 1000-01, 800 P.2d at 562, 275 Cal. Rptr. at 206.

22. See infra Part V.D. 


\section{POLICY JUSTifications For THE ONE-ACTION RULE AND THE SECURITY-FIRST PRINCIPLE}

\section{A. Policy Justifications}

Section 726 does not provide a sanction for violation of its provisions. As a result, the courts have looked to the legislative intent behind the enactment of the statute to determine the propriety of imposing sanctions in various situations and the appropriate scope of the sanctions to be imposed. ${ }^{23}$ The prevention of a multiphicity of actions is most often cited as the driving force behind the enactment and application of the one-action rule. ${ }^{24}$ This rationale protects a defaulting debtor's unencumbered assets from hitigation costs at a time of great financial need. ${ }^{25}$ It also prevents a creditor froin obtaining a judgment lien on everything the debtor owns (tlie result of a judgment on the note or a personal deficiency judgment) in addition to the consensual lien (i.e., mortgage or deed of trust) securing the note. ${ }^{26}$

The courts liave ascribed other policy rationales to section 726 . In Walker v. Community Bank ${ }^{27}$ the California Supreme Court found the

23. The judiciary is solely responsible for creating and mostly responsible for developing oneaction rule sanction doctrine, with academic commentators fueling the controversy. See Munoz \& Rabin, supra note 11, at 209 ("The concept of sanctions for violating the one action rule is purely an invention of the judiciary, as influenced by academic commentators."); see also Rowan \& Mertens, supra note 11, at 78 ("The sanctions for violating CCP $\$ 726$ are all court imposed. The section itself is silent as to what the sanctions should be.").

24. See Salter v. Ulrich, 22 Cal. 2d 263, 266, 138 P.2d 7, 9 (1943) ("[S]ection 726 . . . was inteuded to simplify procedure and to relieve the mortgagor, who was usually the primary debtor, from harassment in repeated litigatiou."); Felton v. West, 102 Cal. 266, 269, 36 P. 676, 677 (1894) ("Formerly the law allowed an action upon a promissory note, and also a suit in equity to foreclose the mortgage .... The mischief in such a practice lay in the multiplicity of suits, and the harassing of the debtor by two actions, when the creditor could readily enforce all his riglits in one."); Ould v. Stoddard, 54 Cal. 613, 615 (1880) ("It is generally conceded that the obvious intention of the Legislature in enacting the statute under consideration was to prevent a multiplicity of suits ...."); Comment, supra note 1, at 430-31 ("The sole intention of the legislature was to make a procedural change that would prevent [the] multiplicity of actions arising under the common law."); supra note 3 and accompanying text.

25. Note, Foreclosing a Single Loan with Multiple Security, 63 CaLIF. L. REv. 152, 154 (1975) (authored by Paul M. Rose).

26. Where a creditor brings an action for judicial foreclosure, omits some of the security from its petition for a decree of foreclosure, and subsequently obtains a personal deficiency judgment following the sale of the security,

the creditor obtains an advance deficiency. It is the creation of this advance defieiencyi.e., the judgment and resulting judgment hen on everything the debtor owns, while the creditor still retains a consensual security interest in the ... property originally put up as security-which so deeply offends the policy of the one-action statute. That policy is to limit a secured creditor to the security which he voluntarily took to secure the obligation in the first instance, and to prevent him from injuring the debtor and prejudieing other creditors by augmenting his unforeclosed consensual lien witl a judgment lien on potentially all of the rest of the debtor's property.

Hetland \& Hansen, supra note 6, at 207.

27. 10 Cal. 3d 729, 518 P.2d 329, 111 Cal. Rptr. 897 (1974). 
purposes of the one-action rule to be: (1) preventing a multiphicity of suits; (2) compelling competitive bidding to test the value of all the security; and (3) forcing the creditor to look to all the security as the primary fund before looking to the debtor. ${ }^{28}$ The second and third purposes announced by the court in Walker are based on the rationale that the parties to the transaction have agreed that the security is to serve as the primary fund for satisfying the obligation, the debtor being secondarily liable contingent upon the exhaustion of the security at a judicial foreclosure sale. ${ }^{29}$ The one-action rule calls for a judicial foreclosure sale at which the value of the security will, theoretically, be determined by coinpetitive bidding. However, a creditor that disregards the one-action rule by suing on the note, or by failing to include all of the security in an action for judicial foreclosure, has obtained a personal judgment against the unencumbered assets of the debtor without giving the debtor the benefit of having the fair market value of the security apphied to reduce the debt. $^{30}$

An analysis of the interaction of section 726(a) with sections 726(b) and 580d of the California Civil Procedure Code supports this reasoning. When a creditor chooses to foreclose judicially, and does so in coinphance with the one-action rule by including all security in the foreclosure action, the court will order the security sold at an execution sale, after which a deficiency judgment will be entered against the debtor for the amount still owed on the debt. ${ }^{31}$ This judgment, however, is limited by section 726(b), which credits the debtor with the fair market value of the security in the event the execution sale produces a below-fair-market

28. Id. at 735, 518 P.2d at 333, 111 Cal. Rptr. at 901; 4 H. MILLER \& M. STARR, supra note 4, $\S 9: 104$ at 343 .

29. See Bank of Italy Nat'1 Trust \& Sav. Ass'n v. Bentley, 217 Cal. 644, 649, 20 P.2d 940, 941 (" $[T]$ he contract between the parties must be held to impliedly provide that the land constitutes the primary fund to secure the debt, and that a sale under the deed of trust will be had before a suit may be commenced on the note."), cert. denied, 290 U.S. 659 (1933); Biddel v. Brizzolara, 64 Cal. 354, 362,30 P. 609, 612 (1883) ("The liability of the mortgagor is ... contingent on the fact that a sale of the mortgaged premises shall fail to satisfy the debt and costs."); CaliforNIA REAl ProperTy FinANCING, supra note $4, \S 3.43$, at 200-01. Gordon Graham provides an excellent synopsis of the primary fund policy:

The loss of any seeurity not included in the foreclosure action is justified on the grounds that this result is consistent with the agreement of the parties; by posting more than one parcel of property as security for the debt, the debtor understands that all of the encuinbered property may be taken if necessary to satisfy the debt. ... [T] he creditor is understood to have agreed to look prinarily to the security for recovery of the debt and not Id. to be entitled to a deficiency judgment unless the security is inadequate.

30. See J. HetLaND, supra note $4, \S 6.18$, at 259 .

31. CAl. Civ. Proc. CoDe § 726(a), (b) (West 1991).

A creditor that is secured by a mortgage or deed of trust containing a power of sale may foreclose, upon default of the debtor, in one of two ways. The creditor could cominence either a private foreelosure action (otherwise known as a nonjudicial foreclosure or a trustee's foreclosure) under the power of sale or a judicial foreclosure. 
final bid. ${ }^{32}$ Furthermore, in the event a creditor chooses to foreclose nonjudicially under a power of sale in the mortgage or deed of trust, a choice that does not trigger the one-action rule, ${ }^{33}$ the creditor may not obtain a deficiency judgment under section 580d. ${ }^{34}$ Thus, the interaction of sections $726(\mathrm{a}), 726(\mathrm{~b})$, and $580 \mathrm{~d}$ creates a statutory antideficiency scheme that finds its roots in the primary fund policy discussed above.

\section{B. The Security-First Principle-A Corollary to the One-Action Rule}

One common thread runs through any discussion of the justifications of the one-action rule. Whetler the policy be preventing a multiplicity of actions, compelling competitive bidding to test the value of the security as the primary fund for satisfaction of the debt, or upliolding Califormia's statutory antideficiency scheine, the one-action rule requires the creditor to foreclose on the security before looking to the debtor's unencumbered assets. ${ }^{35}$ Roger Bernhardt provides an accurate summary of the security-first principle:

Because CCP $\S 726$ bars an independent action on the note, the only method by which a beneficiary may recover froin the trustor's personal estate is by a deficiency judgment after a foreclosure sale has failed to produce enough to satisfy the debt. Thus, CCP $\S 726$ is a security-first rule as well as a one-action rule. ... This security-first principle has the further effect of converting the debtor's promise to pay froin an absolute to a conditional obligation. A California trustor who signs a note does not promise unconditionally to pay the note, but rather promises to pay any deficiency that remains if a sale of the encumbered property does not satisfy the note. ${ }^{36}$

The security-first principle is best termed a corollary to the one-

32. Cal. Civ. Proc. Code § 726(b) (West 1991); see J. Hetland, supra note 4, § 6.1, at 234, $\S 6.18$, at 259 .

33. In Hatch v. Security-First Nat'1 Bank, 19 Cal. 2d 254, 120 P.2d 869 (1942), the court held that where a single debt is secured by several security interests in real property, a creditor can hold several nonjudicial foreclosure sales because the one-action rule is only invoked where the creditor secks more than one judicial action. Id. at 258, 120 P.2d at 872. For a discussion of the implications of Hatch, see J. HETLAND, supra note 4, §6.19, at 260-61.

34. Cal. Civ. Proc. Code §580d (West 1991).

Section 580d was enacted in 1939 to equalize the costs facing a creditor who must choose between nonjudicial and judicial foreclosure. Prior to 1939, a creditor choosing nonjudicial foreclosure was able to obtain the property at the sale by entering a less than full credit bid and also obtain a deficiency judgment for the difference. In contrast, a creditor choosing judicial foreclosure was faced with tine-consuming and costly court procedures as well as with the debtor's statutory right to redecm the property for threc months following the sale under $\$ \$ 725(\mathrm{a})$ and $726 . \mathrm{J}$. HETLAND, supra note $4, \S 6.13$, at 249.

35. Indeed, the Supreme Court of California has described the security-first principle as "hornbook law in California [that] warrants no extended discussion." Security Pac. Nat'1 Bank v. Wozab, 51 Cal. 3d 991, 999, 800 P.2d 557, 561, 275 Cal. Rptr. 201, 205 (1990); see also Munoz \& Rabin, supra note 11, at 206 (citing numerous cases adhering to the sccurity-first principle).

36. R. BERNHARDT, supra note $3, \S 4.4$, at 187-88. 
action rule. It can be looked at as either a pohcy behind the one-action rule, ${ }^{37}$ or as an effect of the application of the one-action rule. ${ }^{38}$ Although Bernhardt describes the security-first principle as an effect of the application of the one-action rule, ${ }^{39}$ modern courts view the securityfirst principle as a policy that inust be adhered to in and of itself. In In re $\mathrm{Kristal}^{40}$ a mortgagee brought an action for judicial foreclosure pursuant to section 726, properly mcluding all of its security in the action. ${ }^{41} \mathrm{How}-$ ever, the creditor proceeded to execute on unencumbered personal property of the debtor prior to holding a foreclosure sale to exhaust the real property security. ${ }^{42}$ The Ninth Circuit held that the creditor's conduct, while not a techurical violation of the one-action rule, "violated the spirit and intent of the statute,"-the security-first principle. ${ }^{43}$ Similarly, in Security Pacific National Bank v. Wozab ${ }^{44}$ the Supreme Court of California decided that when a creditor violates the security-first principle, but does not techirically violate the one-action rule because the creditor's act was not an "action" within the meaning of section 726 , the creditor is nonetheless subject to sanction for violating section $726 .{ }^{45}$

The latter scenario is of particular relevance to this Comment. An improper banker's setoff is a "nonjudicial act" 46 and is therefore not an "action" within the meaning of section $726 .{ }^{47}$ When a bank sets off an unencumbered account before foreclosing on the real property security, such a setoff is nevertheless a violation of the security-first principle. ${ }^{48}$ One of the key questions addressed by this Comment is whether the sanction for violating section 726 imposed when a court finds a violation of the security-first principle embodied in the one-action rule should be different from the sanction imposed when a court finds an ordmary violation of the one-action rule. Given the imterconnectedness of the rule and the principle, it is arguable that the sanction imposed should be the same

37. See Comment, supra note 1 , at 431 ("The court ... has considered the effect of the statute as an expression of legislative purpose and policy, and as a consequence it has become a settled rule of judicial construction in California that where a debt is secured, the security must first be exhausted.").

38. See R. BERNhARDT, supra note $3, \S 4.4$, at 187-88; see also Comment, supra note 1 , at 430 31 (describing security-first principle as an effect of the application of $\S 726$ as opposed to a legislative purpose for enacting $\$ 726$ ).

39. See supra text accompanying note 36 .

40. 758 F.2d 454 (9th Cir. 1985).

41. Id. at 455 .

42. Id.

43. See id.

44. 51 Cal. 3d 991, 800 P.2d 557, 275 Cal. Rptr. 201 (1990).

45. See infra notes $110-15$ and accompanying text.

46. The term "action," for the purposes of $\S 726$, is defined in $\S 22$ as "an ordinary proceeding in a court of justice." CAL. CIV. Proc. CODE $\S 22$ (West 1991).

47. Security Pac. Nat'l Bank v. Wozab, 51 Cal. 3d 991, 998, 800 P.2d 557, 561, 275 Cal. Rptr. 201, 205 (1990).

48. Id. at $999-1000,800$ P.2d at 561-62, 275 Cal. Rptr. at 205-06. 
regardless of the court's rationale. ${ }^{49}$

\section{II}

\section{The Mechanics and Application of the ONE-Action RULE}

When a creditor seeks a personal money judgment without first exhaustimg all security, or omits some of the security for a single debt from an action for judicial foreclosure, ${ }^{50}$ the debtor may raise the oneaction rule as an affirmative defense, forcing the creditor to exhaust the security before proceeding further. ${ }^{51}$ The affirmative defense is based on the judicial interpretation that the one-action rule prohibits a creditor from unilaterally waiving a security interest in real property and seeking a personal judgment. ${ }^{52}$ The reasoning behind preventing a creditor froin circumventing the one-action rule in this manner is that the debtor's personal hability is contingent upon the exhaustion of all of the security. ${ }^{53}$

The one-action rule would have hittle ineaning if, in a creditor's one action, the debtor could not ask the court to coinpel the creditor to exhaust all security for the debt. Without the ability to raise the oneaction rule as an affirmative defense, mortgagors would be at the mercy of their creditors, which would be able to choose freely between either obtaining a judgment on the note and the resulting judgment lien on everything the debtor owns, or alternatively a decree of foreclosure followed by a possible deficiency judgment. The creditor's choice would be a function of the expected inarket value of the security and the "collectability" of the debtor. The affirmative defense is especially iinportant to a debtor who alleges protection under an equitable mortgage ${ }^{54}$ or a

49. See infra Part V.B.

50. The one-action rule may be imvoked by a mortgagor in a variety of situations. Historically, the two most common situations resulting in one-action rule litigation and the development of oneaction rule doctrine are (1) where a creditor omits all of the security for a single debt from its one action by bringing an action directly on the note, and (2) where a multiply secured creditor omits some of its security from an action for judicial foreclosure. See 4 H. MillER \& M. STARR, supra note $4, \S 9: 110$, at 358 n.98.

For an argument that the "one-form-of-action rule may be superfiuous in the multiple security context," see Comment, supra note 25 , at 154 n.12. The applicability of the one-action rule to mixed-collateral situations (real and personal property securing a single debt) is beyond the scope of this Comment. For an in-depth analysis of the issue, see Hetland \& Hansen, supra note 6, and Hirsch, supra note 11 .

51. Walker v. Community Bank, 10 Cal. 3d 729, 734, 518 P.2d 329, 332, 111 Cal. Rptr. 897, 900 (1974).

52. Barbieri v. Ramelli, 84 Cal. 154, 156-57, 23 P. 1086, 1087 (1890).

53. Biddel v. Brizzolara, 64 Cal. 354, 362, 30 P. 609, 612 (1883).

54. See, e.g., Coast Bank v. Minderhout, 61 Cal. 2d 311, 313-15, 392 P.2d 265, 266-67, 38 Cal. Rptr. 505, 506-07 (1964) (agreement not to encumber property treated as mortgage for purposes of judicial foreclosure sale). 
hidden security interest ${ }^{55}$ because the defense allows the debtor to challenge a creditor's classification of a debt as unsecured..$^{56}$

The debtor is not required to raise the affirmative defense, but instead may elect to forgo raising the defense and rely on the one-action rule as a sanction. ${ }^{57}$ Thus, the California Supreme Court has said:

[S]ection 726 is susceptible of a dual application-it may be interposed by the debtor as an affirmative defense or it may become operative as a sanction.... If the debtor does not raise the section as an affirmative defense, he may still invoke it as a sanction against the creditor on the basis that the latter by not foreclosing on the security in the action brought to enforce the debt, has made an election of remedies and waived the security. ${ }^{58}$

Importantly, the sanction becoines operative only after the creditor has reduced its claim to a judgment. ${ }^{59}$ In the case of a creditor that

55. Sometimes the parties may deliberately disguise a secured transaction as a deed absolute, a sale and leaseback, or a sale with an option to repurchase. Their purpose in doing so may be to avoid the usury laws or anti-deficiency judgment legislation, or to achieve a capital gain on resale instead of interest income.

R. MaXwell, S. Riesenfeld, J. Hetland \& W. Warren, California Cases on SEcured Transactions in Land 146 (3d ed. 1984) (citing J. Hetland, Secured Real Estate TRANSACTIONS 66-67 (1974)).

56. 4 H. MILLER \& M. STARR, supra note 4, § 9:104, at 346; see also J. HETLAND, supra note $4, \S 6.3$, at 236 ("The prelude to unmasking a hidden security interest . . . often is the debtor's insistence on his CCP 726 right to compel judicial foreclosure in lieu of any other judicial activity by the creditor.").

57. By waiving the affirmative defense, the debtor does not waive the one-action rule sanction. Walker, 10 Cal. 3d at 734, 518 P.2d at 332, 111 Cal. Rptr. at 900; 4 H. MILleR \& M. STARR, supra note $4, \S 9: 104$, at $346-47$; 3 B. WITKIN, supra note 11 , $\S 119$, at 621 ; Comment, supra note 25 , at 154.

The affirmative defense gives the debtor the power to compel the creditor to include all security in its action. By waiving the defense, the debtor waives the benefits of the defense-the right to compel the creditor to exhanst all of the security first. However, the courts have held that a waiver of the affirmative defense does not affect the debtor's right to invoke the one-action rule sanction, which includes loss of the creditor's rights in the security. See Leipziger, supra note 12, at 790 n.104. But see United California Bank v. Tijerina, 25 Cal. App. 3d 963, 102 Cal. Rptr. 234 (1972).

In Tijerina the court refnsed to impose a $\$ 726$ sanction where the debtor failed to raise the oneaction rule affirmative defense during a judicial foreclosure action and then, in an attempt to prevent the entry of a deficiency judgment, sought to invoke the one-action rule sanction after the security was sold. Tijerina, $25 \mathrm{Cal}$. App. 3d at 967-69, $102 \mathrm{Cal}$. Rptr. at 237-38. The court held that issues as to the availability of a deficiency judgment inust be raised before the entry of a decree of foreelosure and that the debtor was, therefore, estopped from asserting that the creditor had omitted some security from the foreclosure action. Id. However, the holding was infiuenced by the fact that the debtor had full knowledge of the omission at the time the decree of foreclosure was issued and intentionally remained silent so as to reap the benefits of the one-action rule sanction. See id.; see also $4 \mathrm{H}$. Miller \& M. STARR, supra note 4, §9:111, at $360 \mathrm{n} .7$ ("[W] here the debtor has the opportunity to raise the defense but he is intentionally silent, the debtor should be estopped from 'trapping' the creditor, and the creditor should be allowed to enforce the debt."); Leipziger, supra note 12, at $804 \mathrm{n} .145$ (rule announced in Tijerina is that courts will not indulge "a debtor who deliberately withholds assertion of C.C.P. 726 as an affirmative defense in an effort to trap his creditor into the C.C.P. 726 sanction effect and loss of a deficiency judgment").

58. Walker, $10 \mathrm{Cal}$. 3d at 734, 518 P.2d at 332, $111 \mathrm{Cal}$. Rptr. at 900.

59. "The sanction effect of section $726 \ldots$ is triggered when a creditor proceeds to take a 
brings an action directly on the note, the creditor's claim is said to be reduced to a judgment when the creditor obtains a personal money judgment from the court. ${ }^{60}$ In contrast, in the case of a creditor that omits security from an action for judicial foreclosure, the point at which the creditor's claim is reduced to judgment is not as obvious. The difficulty arises because the creditor's one allowable action under section 726 involves three important, temporally distmct events.

The first such event is the issuance of a decree of foreclosure, which states the amount of the indebtedness, identifies the real property security to be sold, and names the debtor as being personally liable on that portion of the debt deemed unsatisfied following the foreclosure sale. ${ }^{61}$ The second event is the foreclosure sale held pursuant to the decree of foreclosure. ${ }^{62}$ The final event in the creditor's one action that might reasonably be considered the point at which the sanction becomes operative is the entry of a personal deficiency judgment at the deficiency hearing following the foreclosure sale. ${ }^{63} \mathrm{~A}$ personal deficiency judgment will be entered for the amount by which the debt exceeds the greater of the sale proceeds or the market value of the security. ${ }^{64}$

Prior to the occurrence of the issuance of a decree of foreclosure, it is clear that the debtor may raise the one-action rule affirmative defense to compel the creditor to include all of its security in the foreclosure action. ${ }^{65}$ It is equally clear that after the entry of a personal deficiency judgment, the one-action rule operates to bar any further action on the debt, including an action on any security omitted from the foreclosure proceedings. ${ }^{66}$ However, while it is clear that the creditor's claim is not

judgment . . . for less than the full amount of the debt . . ." Hetland \& Hansen, supra note 6, at 205-06; see also $4 \mathrm{H}$. MILleR \& M. STARR, supra note 4, § 9:105, at 348 ("[W]hen the creditor recovers a personal money judgment against the debtor without first foreclosing on all of the security, the sanctions of the "one-action" rule are applied . . ."); cf. Walker, $10 \mathrm{Cal} .3 \mathrm{~d}$ at 740, 518 P.2d at 336, 111 Cal. Rptr. at 904 ("[W] hen the bank failed to inelude the real property security and thereby failed to exhaust all security before obtaining a deficiency judgment, it automatically triggered the sanction aspect of section 726 ...."); Stillman, supra note 12, at 9 (under the combined loss-of-security and loss-of-debt sanction, "any remaining portion of the debt not reduced to judgment" is lost). But see Hall v. Arnott, 80 Cal. 348, 355, 22 P. 200, 202 (1889) (imposing combined loss-of-security and loss-of-debt sanction even though no personal judgment had been entered on the debt).

60. Cf. Ould v. Stoddard, $54 \mathrm{Cal} .613,615$ (1880) (holding that by proceeding with an action upon a note secured by a mortgage to final judgment, a creditor exhausts its remedy upon both the note and security).

61. The reqnired substance of the decree of foreclosure and the procedures for obtaining one are statutorily defined. CAL. Civ. Proc. CODE § 726(a), (b) (West 1991).

62. Id.

63. Id. $\$ 726(\mathrm{~b})$.

64. Id.

65. See J. Hetland, Secured Real Estate Transactions $193-94$ (1974) ("[t]he defense may be waived subsequent to making the loan, most often by failure to plead" the defense when answering a petition for judicial foreelosure).

66. See supra note 59. 
treated as having been reduced to a judgment prior to the issuance of a decree of foreclosure, and while it is clear that the creditor's claim is treated as having been reduced to a judgment at the time of entry of a personal deficiency judgment, it is not clear whether the issuance of a decree of foreclosure effectively reduces the creditor's claim to a judgment. ${ }^{67}$

There are two reasons why the issuance of a decree of foreclosure might reasonably be considered the point at which the creditor's claim is reduced to a judgment and the sanction becomes operative. First, the decree of foreclosure contains sufficient information to be considered a binding judgment-it states the amount of the indebtedness, identifies the real property security to be sold, and names the debtor as being personally hable on that portion of the debt deemed unsatisfied following the foreclosure sale. ${ }^{68}$ Second, if the issuance of a decree of foreclosure is not considered the point at which the sanction becomes operative, it would seem to follow that a debtor could raise the one-action rule affirmative defense at any time after the issuance of the decree of foreclosure. ${ }^{69}$

Despite the practical arguments for declaring the issuance of a decree of foreclosure as the point at which the creditor's claim is said to be reduced to judgment, one-action rule sanction doctrine strongly suggests that the entry of a personal deficiency judgment is the dispositive

67. United California Bank v. Tijerina, 25 Cal. App. 3d 963, 102 Cal. Rptr. 234 (1972), suggested that the issuance of the decree of foreclosure is the point at which the creditor's claim is reduced to judgment. In Tijerina the court held that once the decrec of foreclosure is issued, all that is left for the court to determine "is the amount, if any, of the deficiency remaining after sale of the mortgaged property. ... The section [ $\$ 726]$ obviously contemplates that all other issues have been adjudicated prior to the entry of the deerce of foreelosure." Id. at 968, 102 Cal. Rptr. at 237. In other words, the court read $\$ 726$ to mean that once the decree of foreelosure is issued, the debtor's substantive protections under the statute are forever waived. Thus under Tijerina, the issuance of the decrce of foreclosure seems to be the point at which the debtor is deemed to have waived its right to compel the creditor to foreelose on all security and, therefore, the point after which the one-action rule sanction may be raised by the debtor.

68. Cal. Crv. Proc. Code. § 726(b) (West 1991); see also Tijerina, 25 Cal. App. 3d at 968, 102 Cal. Rptr. at 237 ("The first stage, culminating in the decree of foreclosnre, orders the sale of the mortgaged property and determmes whether the defendant is personally liable for the debt and subject to the entry of a deficiency judgment.").

69. Allowing the debtor to raise the one-action rule affirmative defense after the issuance of a decree of foreclosure does not seem to comport with the statutorily defined process of judicial foreclosure. Under $\$ 726$, a mortgagee must file a petition for judicial foreelosure direeting the court to foreclose on the real property securing the debt. In its discretion, the conrt may then issue a decree of foreclosure describing the real property to be sold as identified in the creditor's petition for foreclosure. Id. $\S 726(\mathrm{a})$. When a creditor neglects to identify all real property securing the debt in its petition for foreclosure, the debtor has the opportunity to raise the one-action rule affirnative defense prior to the issuance of a decree of foreclosure. See Tijerina, 25 Cal. App. 3d at 968-69, 102 Cal. Rptr. at 238. If the debtor fails to raise the affirnative defense and the deeree of foreclosure is issued as per the creditor's petition, the debtor is deemed to have waived the right to compel the creditor to include the omitted security in the foreclosure action. See J. HeTland, supra note 4, $\S 6.10$, at 243 . 
event. In Walker v. Community Bank ${ }^{70}$ the Supreme Court of California held that "when the bank failed to include the real property [in the judicial foreclosure action] and thereby failed to exhaust all security before obtaining a deficiency judgment, it automatically triggered the sanction aspect of section 726 and thereby lost all security rights in the real property."71 The Walker court's doctrinally correct analysis relies equally on the security-first principle $\mathrm{e}^{72}$ and the dual-hen-avoidance principle ${ }^{73}$ of the one-action rule, the imphicit assumption in the court's analysis being that the one-action rule is not offended until a creditor obtains a personal judgment against the debtor while still retaining an unforeclosed-on, consensual, real property security interest. Thus under Walker, in order for the sanction to operate im the context of a judicial foreclosure, the creditor must have failed to foreclose on all security for the debt and must have subsequently obtained a personal deficiency judgment--the occurrence of the latter event triggering the one-action rule sanction. ${ }^{74}$

This solution does not, however, address the issues of whether a debtor may raise the affirmative defense after the issuance of a decree of foreclosure and whether a creditor can ask the court to "amend" a decree of foreclosure to include a previously omitted parcel of real property security without bringing a one-action rule sanction upon itself. The dearth of authority on these issues has created a gap of inapplicability for the one-action rule's substantive protections-a gap that spans the period beginning with the issuance of a decree of foreclosure and ending with the entry of a personal deficiency judginent.

When confronted with these issues, future courts should look to the

70. 10 Cal. 3d 729, 518 P.2d 329, 111 Cal. Rptr. 897 (1974).

71. Id. at 740,518 P.2d at 336, 111 Cal. Rptr. at 904 (emphasis added).

72. See supra Part I.B.

73. See supra note 26 and accompanying text.

74. This rule is the result of what Professor Hetland describes as "modern one-action analysis." Hetland \& Hansen, supra note 6, at 206 n.78 ("If a creditor elects to obtain a judgment for less than the full amount of a single debt, he keeps the judgment but loses everything else."). For a thorough look at the mechanics of "modern one-action analysis," see infra Part III.B.

Under "early one-action analysis," Hetland \& Hansen, supra note 6, at 206 n.78, the rule as to when the one-action rule sanction became operative was slightly different. Professor Hetland describes the theory behind the early analysis as follows: "[I]f the creditor [is] allowed only one action, he [can] not have another, so anything excluded from the first judgment [is] necessarily waived, there being no means to enforce it." Id.; see also infro note 92 . Courts applying the "early one-action analysis" imposed the one-action rule sanction in partial foreclosure situations to deprive the offending creditor of a personal deficiency judgment. In these cases, the one-action rule sanction effect was not triggered by the entry of a personal money judgment, but rather by an event that made it impossible for the creditor to exhaust all security for the debt by judicial foreclosure sale. See, e.g., Woodward v. Brown, 119 Cal. 283, 292-94, 51 P. 2, 4 (1897) (refusing to enter deficiency judgment where creditor unilaterally waived part of security for the debt); Hall v. Arnott, 80 Cal. 348, 355, 22 P. 200, 202 (1889) (holding that when a creditor brings an action for judicial foreclosure, omits some of the security from the action, and sues for less than the entire debt, the creditor is deemed to have waived the unforeclosed-on security as well as that portion of the debt not sued for, even though no personal deficiency judgment has been entered on the debt). 
statutorily defined procedures for the one-action rule in fashioning or denying relief. Curiously, such an analysis suggests that the gap of inapplicability described above may be inevitable. For example, as to the first issue, whether a debtor may raise the affirmative defense after the issuance of a decree of foreclosure, a court should probably deny relief on the grounds that the affirmative defense, which coinpels a creditor to include all of its security in the foreclosure action, must be raised prior to the issuance of the document directing the sale of property identified in the creditor's petition for foreclosure as security for the debt. Put simply, unless the debtor objects to a petition that fails to identify all security for the debt, the debtor has waived the right to compel the creditor to foreclose on all security for the debt. As to the second issue, whether a creditor can ask the court to amend a decree of foreclosure, a court should probably grant rehef on the grounds that "amending" a decree of foreclosure to include a previously omitted real property security interest would not be the same as subjecting the debtor to another action because the creditor's one allowable action under section 726 is not complete until the court renders its judgment at the deficiency hearing.

The dual application of the one-action rule-as an affirmative defense and as a sanction-raises an interesting problem in the context of an inproper banker's setoff. A banker's setoff is a unilateral act of a nonjudicial nature. Therefore, an improper banker's setoff deprives the debtor of the opportumity to assert the section 726 affirmative defense to prevent unencuinbered assets froin being seized prior to exhaustion of all security. At the same time, the bank inay be faced with an automatic section 726 sanction without an opportunity to reverse the transaction in cases of inadvertent error because the unilateral act of setoff is analogous to the entry and simultaneous enforcement of a personal judgment by a court. In Wozab the court attempted to address this problem by suggesting that if proinptly returned, an inadvertent setoff should not trigger one-action rule consequences. ${ }^{75}$

\section{III}

\section{THE SCOPE-OF-THE-SANCTION CONTROVERSY}

The scope-of-the-sanction controversy involves the question of whether the proper sanction for violating section 726 is loss of the security interest only, or alternatively loss of both the security interest and that portion of the underlying debt not reduced to judgment by the creditor's one action. ${ }^{76}$

75. Security Pac. Nat'l Bank v. Wozab, 51 Cal. 3d 991, 1001 n.8, 800 P.2d 557, 563 n.8, 275 Cal. Rptr. 201, 207 n.8 (1990).

76. See supra notes 11-12 and accompanying text.

Professor Edward Rabin sheds a different light on the controversy by suggesting that the 


\section{A. Loss of Security Only}

The doctrine of election of remedies is a commonly suggested rationale for imposing the loss-of-security-only sanction on a creditor that has violated section 726. The doctrine is based on the theory that when a creditor sues on the note and thereby obtains a personal judgment, the creditor is deeined to have chosen the personal judgment as the sole remedy in heu of resorting to the security. ${ }^{77}$ The doctrine of election of reinedies supports imposing a loss-of-security-only sanction when a creditor brings an action directly on the note and the debtor fails to raise the one-action rule affirmative defense. In that situation, the action on the note is the creditor's one action under section 726 and the creditor, now unsecured, is deeined to be satisfied by the personal judgment. ${ }^{78}$ However, the operation of the one-action rule is not so simple.

Consider the situation in which a creditor brings an action for judicial foreclosure but mistakenly omits soine of its security from the action. If the debtor fails to raise the section 726 affirmative defense and the court subsequently enters a personal deficiency judgment following the sale of the inortgaged premises, the creditor has obtained a valid and enforceable judgment. This judgment is the result of the creditor's one action under section 726. Accordingly, no other action on the debt is permitted. As a result, when a creditor in the situation described above also mistakenly sues for less than the entire debt and obtains a personal deficiency judgment based on the imcorrect stateinent of indebtedness, the creditor is deemed to have lost the unincluded portion of the debt. ${ }^{79}$ Any reinaining unforeclosed-on security is necessarily lost because there is no debt left to be secured-all that remains is an unsecured personal deficiency judgment. ${ }^{80}$

By analogy, when a creditor, ignoring the security, brings an action directly on the note and therefore necessarily sues for the full amount of the debt as evidenced by the note, there is no debt left to be waived. Of course, the security is deeined to be waived because there is no debt left to be secured-all that is left is an unsecured personal judgment. Curiously, this simple analysis, which is grounded in basic secured transac-

concept of sanctions is entirely misplaced in the context of $\S 726$ violations. He argues that the results in one-action cases can best be described in terms of merger of claims. See Munoz \& Rabin, supra note 11 , at 210 .

77. See Ould v. Stoddard, $54 \mathrm{Cal}$. 613, 615 (1880) (holding that by proceeding with an action upon a note secured by a mortgage to final judgment, a creditor exhausts its remedy upon both the note and security). Leipziger notes that the election is really in the hands of the debtor because the creditor cannot sue on the note in lieu of foreclosure unless the debtor fails to raise $\S 726$ as an affirmative defense. Leipziger, supra note 12, at 788.

78. Ould, $54 \mathrm{Cal}$. at 615.

79. See Hetland \& Hansen, supra note 6 , at 206 \& n.78.

80. See id. at 206. 
tions law, has caused a great deal of confusion. ${ }^{81}$

Commentators supporting the loss-of-security-only sanction often bolster their contention that there is no other proper sanction by citing cases in which that sanction was applied. Walker v. Community Bank ${ }^{82}$ and Salter v. Ulrich ${ }^{83}$ are two such commonly cited cases. In Walker the court held that by judicially foreclosing on personal property collateral and obtaining a deficiency judgment without including the real property security in the foreclosure action, the creditor violated the one-action rule. ${ }^{84}$ The court imposed the sanction of loss of the security but noted that the bank could still "levy execution upon any of [the debtor's] property in order to satisfy the deficiency judgment." 85 In other words, although the debt was satisfied by the entry of a personal deficiency judgment and was therefore no longer in existence, the bank could still effectively "collect on the debt" by enforcing its personal deficiency judgment.

Similarly, in Salter the court held that a creditor, who obtained a personal judgment on a note upon the default of the debtor and thereafter foreclosed on and purchased at a foreclosure sale the property securing the debt in partial satisfaction of the debt, lost his hen priority over a judgment lienor who had purchased the same property at a different foreclosure sale. ${ }^{86}$ Thus, the creditor lost his rights in the security interest but retained the right to enforce the personal money judgment.

The argument that the sanction for violation of the one-action rule should never include loss of the debt because cases like Walker and Salter resulted in a less harsh sanction is highly questionable because the creditors in both cases obtained a valid judgment for the full amount of the debt. ${ }^{87}$ As noted above, when a creditor ormits some or all of its security from its one action, the one-action rule bars any further action on the debt. ${ }^{88}$ When the same creditor obtains a vahd judgment for the full ainount of the debt, the one-action rule's prohibition of any further action on the debt is rendered moot. Of course, the unforeclosed-on security is deemed to be waived because there is no debt left to be secured-all that remains is an unsecured personal judgment.

For lack of an adequate argument based in one-action rule doctrine,

81. See infra Part V.B.

82. 10 Cal. 3d 729, 518 P.2d 329, 111 Cal. Rptr. 897 (1974).

83. 22 Cal. 2d 263, 138 P.2d 7 (1943).

84. Walker, $10 \mathrm{Cal}$. 3d at 741, 518 P.2d at 337, 111 Cal. Rptr. at 905.

85. Id. at 741 \& n.6, 518 P.2d at $337 \&$ n.6, 111 Cal. Rptr. at $905 \&$ n.6.

86. Salter, $22 \mathrm{Cal} .2 \mathrm{~d}$ at 268,138 P.2d at 9-10.

87. Walker, $10 \mathrm{Cal}$. 3d at 741, 518 P.2d at 337, 111 Cal. Rptr. at 905; Salter, $22 \mathrm{Cal} .2 \mathrm{~d}$ at 265, 138 P.2d at 8; see also United California Bank v. Tijerina, 25 Cal. App. 3d 963, 967-69, 102 Cal. Rptr. 234, 236-38 (1972) (refusing to impose loss-of-debt sanction where creditor obtained a personal deficiency judgment for full amount of debt and where debtor intentionally failed to raise the oneaction rule affirmative defense prior to issuance of decree of foreclosure).

88. See supra text accompanying notes $79-81$. 
other commentators resort to a fairness argument to advocate the loss-ofsecurity-only sanction and criticize the harsher dual sanction. One commentator argues that if one of the purposes of imposing a sanction is to deter future violations of the one-action rule, reducing the creditor to the status of an unsecured creditor is a sufficient deterrent in that it "materially diminishes the chances or amount of any ultimate recovery, especially im the shadow of the Bankruptcy Code."89 In the context of improper banker's setoffs, another commentator opines: "Assuming that the setoff was improper, the sanction imposed [loss of the security and the debt] violates the principle of proportionality. Damages or sanctions imposed for the commission of a wrong should bear some reasonable relation to the wrongfulness of the act and the damages caused by it."90 Indeed, the Supreme Court of California resorted to a fairness argument im holding that the loss-of-debt sanction was inappropriate in inost improper banker's setoff cases. ${ }^{91}$ Policy arguments like these dominate the rhetoric of critics of the harslier sanction, rendering the academic debate unproductively nonresponsive - one side arguing pure policy, the other pure doctrine.

\section{B. Loss of Security and Debt}

Professor Hetland's commonsense argument in support of imposing the combined loss-of-security and loss-of-lebt sanction is that if a creditor takes a judgment for less than the full amount of the debt prior to the exhaustion of all security, the creditor may not have another action on the unincluded portion of the debt. ${ }^{92}$ In other words, any portion of the

89. Arnold, supra note 11, at 3; see also Security Pac. Nat'1 Bank v. Wozab, 51 Cal. 3d 991, 1001, 800 P.2d 557, 562, 275 Cal. Rptr. 201, 206 (1990) (noting the predictable position of the California Banker's Association that "loss of the security is by itself sufficiently drastic to deter improper setoffs"); Hirsch, supra note 11, at 52-53 (Amold, as co-author, arguing that if goal of the "sanction aspect" is to deter violations of $\S 726$, loss-of-security sanction is sufficiently daunting). Leipziger adds support to the argument that loss of security may be a harsh enough sanction in itself:

[T] he lender will not be able to enforce [a personal] judgment by levying on the formerly encumbered property if the debtor has sold it before recordation of an abstract of the judgment, and even if he does levy successfully, he may have a lower priority than he formerly had under his mortgage because of intervening liens. Leipziger, supra note 12, at 789 (citations omitted).

90. Munoz \& Rabin, supra note 11 , at 208.

91. See Security Pac. Nat'1 Bank v. Wozab, 51 Cal. 3d 991, 1005-06, 800 P.2d 557, 568, 275 Cal. Rptr. 201, 213 (1990) ("[T]he result advocated by the Wozabs-allowing them to evade their debt almost in its entirety-would be a gross injustice to the bank and a corresponding windfall to the Wozabs." (citing Mertens, California's Foreclosure Statutes: Some Proposals For Reform, 26 SaNta Clara L. Rev. 533, 555 (1986))).

92. Put simply, "[i]f a creditor elects to obtain a judgment for less than the full amount of a single debt, he keeps the judgment but loses everything else." Hetland \& Hansen, supra note 6, at 206 n.78; see also supra text accompanying notes 79-80.

Another commonly argued rationale in support of imposing the combined loss-of-security and loss-of-debt sanction is that the exhaustion of all security by the creditor is a condition precedent to the availability of a personal judgment against the debtor. See J. HeTLAND, supra note $4, \S 6.18$, at 
debt that is not included in the creditor's action, and is therefore not included in the creditor's judgment, is deemed to be waived. Any remaining unforeclosed-on security is necessarily waived because there is no debt left to be secured. ${ }^{93}$

For example, when a creditor forecloses to recover on a debt secured by multiple parcels of real property but inadvertently omits one of the parcels froin the foreclosure proceedings, the creditor has waived any umincluded portion of the debt because the creditor has already had one action. Furthermore, because a security interest is unenforceable without an underlying debt, any omitted security is also necessarily waived. Similarly, when a bank improperly sets off a debtor's unencumbered bank account, one could argue that the setoff is the equivalent of an "action" under section 726, and that therefore any subsequent attempt to foreclose on the real property security or to collect from the debtor personally would be barred by the waiver of debt and waiver of security inechamism. ${ }^{94}$

Courts in several inultiple-security cases have imposed the combined loss-of-security and loss-of-debt sanction. ${ }^{95}$ The seminal case of this

258; 4 H. Miller \& M. STARR, supra note 4, § 9:111, at 361 n.8; Arnold, supra note 11, at 3; Weiner \& Tramz, supra note 11, at 2. Professor Hetland provided a complete statement of this rationale in his 1970 treatise:

A prerequisite to a personal judgment against the debtor is exhaustion of all the security

for the debt. ... . Having brought one action to judgment without exhausting all security, the creditor may not have another action to exhaust the balance. Since a deficiency or personal judgment against the debtor depends on the now-impossible exhaustion of all security, the debtor also escapes liability on whatever balance remains on the debt. Thus, the sanction for failure to exhaust all ... security for the same debt in one action ... [is] a waiver of the remaining security as well as a waiver of the balance of the debt.

J. HETLAND, supra note 4, § 6.18, at 258 (citing Stockton Savings \& Loan Soc'y v. Harrold, $127 \mathrm{Cal}$ 612, 60 P. 165 (1900), and Hall v. Amott, 80 Cal. 348, 22 P. 200 (1889)). This rationale, which Professor Hetland describes as "early one-action analysis," Hetland \& Hansen, supra note 6, at 206 n.78, has been criticized by loss-of-security-only advocates as "unduly formalistic" and involving "rather circular reasoning." Amold, supra note 11, at 3.

93. See Hetland \& Hansen, supra note 6, at 206 \& n.78. Even if the creditor in the situation presented did foreclose on all its security, the one-action rule would still prevent the creditor fron collecting that portion of the debt not reduced to judgment. For example, a creditor that brings an action for judicial foreclosure and forecloses on all its security, but madvertently fails to sue for the full amount of the debt and therefore fails to obtain a judgment on the full amount of the debt, is barred by the one-action rule from bringing any further action to collect on the unincluded portion of the debt even though the creditor did not violate the security-first principle. See Hetland \& Hansen, supra note 6, at 205-06.

94. See R. BernhardT, supra note $3, \S 4.5$ at 190. In Bank of America v. Daily, $152 \mathrm{Cal}$. App. 3d 767, $199 \mathrm{Cal}$. Rptr. 557 (1984), the court found merit in this very argument and imposed a conibined loss-of-security and loss-of-debt sanction. See id. at 772-74, $199 \mathrm{Cal}$. Rptr. at 559-60; infra note 137. In Seeurity Pac. Nat'1 Bank v. Wozab, 51 Cal. 3d 991, 800 P.2d 557, 275 Cal. Rptr. 201 (1990), however, the Supreme Court of California rejected this argument, reversing Daily in part. Id. at 998-99 \& n.7, 800 P.2d at 560-61 \& n.7, 275 Cal. Rptr. at 204-05 \& n.7. For an analysis of the Daily and Wozab opinions, see infra Parts IV \& V.

95. See, e.g., Stockton Savings \& Loan Soc'y v. Harrold, 127 Cal. 612, 616-17, 60 P. 165, 168- 
type, Hall v. Arnott, ${ }^{96}$ involved a inortgagor who defaulted on a debt secured by two parcels of real property. The creditor judicially foreclosed on one of the parcels and erroneously sued for less than the full amount of the debt. Following the foreclosure sale, a deficiency of $\$ 1800$ remaimed as to the amount sued on, and a deficiency of $\$ 2500$ remained as to the total amount of the debt. The debtor then sold the unforeclosed-on property and the purchaser sought to clear title as between the creditor and himself by tendering $\$ 1800$ to the creditor. The creditor refused, arguing that he was entitled to the full $\$ 2500$ deficiency representing the amount owing on the entire debt after the foreclosure sale. ${ }^{97}$ The supreine court held that the creditor's failure to foreclose on the second parcel of property during the foreclosure action extinguished the creditor's interest in the unincluded portion of the debt and in the omitted security. ${ }^{98}$ Thus under $\mathrm{Hall}$, when a creditor judicially forecloses on less than all of the security and sues for less than the entire debt in the foreclosure action, the creditor may not bring another action on the debt, and is therefore deeined to have waived the umincluded balance of the

69 (1900); Woodward v. Brown, 119 Cal. 283, 292-94, 51 P. 2, 4 (1897); Hall v. Arnott, 80 Cal. 348, 350-51, 22 P. 200, 202 (1889).

Commentators supporting the combined loss-of-security and loss-of-debt sanction often cite Woodward v. Brown, $119 \mathrm{Cal}$. 283, 51 P. 2 (1897), as dispositive. However, that case involved a creditor who unilaterally and intentionally released hens on several parcels of real property and then sought to obtain a personal judgment against the debtor. Id. at 292-94, 51 P. at 4. Thus, Woodward nay be limited to situations in which the creditor unilaterally releases a security interest in real property with the intent of circuinventing the one-action rule. See Hirsch, supra note 11, at 51-52 (noting that courts treat the debt as extinguished when the secured party unilaterally waives or releases its real property security and suggesting that such cases are distinguishable from cases involving the omission of security from an action for foreclosure); see also Hibernia Sav. \& Loan Soc'y v. Thornton, 109 Cal. 427, 429, 42 P. 447, 448 (1895) ("[W] hen [a] inortgagee, by his own act or neglect, deprives himself of the right to foreclose the inortgage, he at the same time deprives himself of the right to an action upon the note."); Pacific Valley Bank v. Schwenke, 189 Cal. App. 3d 134, 141-42, $234 \mathrm{Cal}$. Rptr. 298, 302 (1987) (holding that reconveyance of a deed of trust froin the creditor to the mortgagor released a comaker of the note from liability for a violation of $\S 726$ wherc the coinaker had no knowledge of the reconveyance).

96. 80 Cal. 348,22 P. 200 (1889).

97. Hall, $80 \mathrm{Cal}$. at 350-51, 22 P. at 201; see also Hirsch, supra note 11, at 49-50 (describing the complex facts presented in Hall); Comment, supra note 25, at 155 (saine).

98. Hall, $80 \mathrm{Cal}$. at 354-55, 22 P. at 202 ("[H]]aving waived their first inortgage . . . [tlie creditors] exhausted their security, and could not obtain a personal judgurent for any deficiency, until they exhausted their security . . . by sale on foreclosure."); accord Stockton Sav. \& Loan Soc'y v. Harrold, $127 \mathrm{Cal} .612,616-17,60 \mathrm{P} .165,168$ (1900) ("[W] distinct mortgages the foreclosure of but one of these has the effect to waive and nullify the lien of the other. . . . [T] The remedy of foreclosure being waived in part, the personal liability of the mortgagor is also waived.") (citations omitted); see also Leipziger, supra note 12, at 789 n.104 (Where a creditor has "several notes as well as several properties as security[,] [t]he first foreelosure under such circumstances may not result in a deficiency on the particular notc involved in that foreclosure, [and] an attempt to collect the balance of the debt represented by the other notes is treated like an attempt to collect a deficiency and is barred for failure to have exhausted the security in the first sale."). 
debt as well as the unforeclosed-on security..$^{99}$

Professor Hetland's analysis is complemented by the writimgs of Professor Leipziger, who argues that the combined loss-of-security and loss-of-debt sanction should be available only in certain circumstances. ${ }^{100}$ Leipziger begins his analysis by setting out the inodel facts under which the harsher sanction has been imposed-when the "debt is secured by more than one item of collateral and the lender neglects to include [the] entire security im the one foreclosure action allowed." 101 He then argues, as does Hetland, that the appropriate sanction in this situation is loss of the security and loss of the debt. ${ }^{102}$

At this point Leipziger further defines the circumstances under which this sanction nay be properly imposed. In addition to the creditor's failure to mclude all of the security in the foreclosure action, the creditor must have "also neglected to sue on all the notes in the same action"103 and the multiple notes must be "cross collateralized so that they are all part of the same obligation."104 The holding in Walker $v$. Community Bank ${ }^{105}$ supports Leipziger's limitation of the application of the combined loss-of-security and loss-of-debt sanction. The rule announced in Walker, Leipziger notes, is that "[w] here the lender holds only one note ... he can recover a personal judginent on the entire debt without including all the security in the action, so long as the debtor has failed to plead C.C.P. 726 as an affirmative defense."106 Although the

99. The purchaser of the unforeclosed property was required to pay the creditor "the remainder due upon the decree of foreclosure." Hall, $80 \mathrm{Cal}$. at $355,22 \mathrm{P}$. at 202 . Thus, the redemption amount was held to be $\$ 1800$ (the amount of the debt sued on less the proceeds of the foreclosure sale) and not $\$ 2500$ (the total amount of the debt less the proceeds of the foreclosure sale). This interpretation is consistent with Professor Hetland's and Professor Leipziger's analysis of the proper sanction to impose where a multiply secured creditor omits security froin a judicial foreclosure action and fails to sue on all of the notes. See infra notes 100-09 and accompanying text. The ouly inconsistency, which stems from the fact that Hall was decided under "early one-action analysis," is that the sanction in Hall was imposed even though a personal judgment had not yet been entered. See supra note 74 and accompanying text.

100. See Leipziger, supra note 12 , at 789 \& n.104.

101. Id. at 789. The paradigm case in which the loss-of-security and loss-of-debt sanction has been imposed involves a multiply secured creditor that omits security from a judicial foreclosure action. See J. HeTLAND, supra note $4, \S 6.18$, at 258.

102. See Leipziger, supra note 12 , at $789 \&$ n.104. Here Leipziger and Hetland differ in form but not in result. Leipziger argues that the interaction of the loss-of-security sanction with the debtor's waiver of the affirmative defense results in a loss of the debt, see id., while Hetland argues that the sanction in such a situation is loss of the security and loss of the debt, see supra text accompanying notes $92-93$.

103. Leipziger, supra note 12 , at 789 n.104.

104. Id. If the notes are not cross-collateralized, it would be more difficult for the debtor to prove that the notes represent a single debt. See J. HeTLAND, supra note $4, \S 6.12$, at 248 (Where "the parties break the [loan amount] into distinct amounts represented by separate notes that are independently secured or partially unsecured, they have separate debts.").

105. 10 Cal. 3d 729, 518 P.2d 329, 111 Cal. Rptr. 897 (1974).

106. Leipziger, supra note 12 , at 790 n.104. 
bank in Walker omitted real property collateral from its judicial foreciosure action, it sued for the entire debt and therefore obtamed an enforceable personal deficiency judgment representing the amount owing on the entire debt after the foreclosure sale. ${ }^{107}$

Thus, Leipziger argues that a creditor inust fail to sue on the entire debt and therefore fail to obtain a judgment representing the amount owing on the entire debt in order for the harsher sanction to operate. ${ }^{108}$ This distinction is of great importance because a inuitiply secured creditor who omits some of the security from a judicial foreclosure action is likely to neglect to sue on the entire debt. For example, when a single debt is expressed by several notes each of which is imdependently secured, the creditor may erroneously beheve that each item of security represents a separate debt. In other words, the creditor may think that there are several independently secured debts and, accordingly, may proceed against only part of the security and sue for less than the entire obligation in the foreclosure action. ${ }^{109}$ Furthermore, when a single debt is expressed by a single note secured by inore than one inortgage or deed of trust, the creditor inay erroneously behieve that each consensual lien represents a certain portion of the debt. Agam, the creditor inight proceed against only part of the security and sue for less than the entire obligation in the foreclosure action.

\section{IV}

\section{THE SANCTION CONTROVERSY IN IMPROPER BANKER'S SETOFF CASES}

California courts have consistently held that an improper banker's setoff may violate section $726 .{ }^{110}$ However, the reasoning empioyed has not been consistent. The mconsistency stems froin the ambiguity of the

107. Walker, $10 \mathrm{Cal} .3 \mathrm{~d}$ at $732-33,518 \mathrm{P} .2 \mathrm{~d}$ at $331,111 \mathrm{Cal}$. Rptr. at 899.

108. Leipziger, supra note 12 , at 790 n. 104.

Professor Hetland's 1970 treatise might suggest that he has not so limited the application of this sanction: The debtor "may ignore [the affirmative] defense and rely instead on the subsequent CCP 726 sanctions-the creditor's loss of the balance of the debt and the balance of the security, which occurs only if the creditor has taken a judgment that fails to foreclose on all the security in the same action." J. HETLAND, supra note 4, § 6.10, at 243. However, Hetland's 1987 article analyzing the mixed collateral amendments places Hetland and Leipziger on common ground. See Hetland \& Hansen, supra note 6, at 205-06.

109. For a discussion of the issue of when multiple notes represent a single debt as opposed to separate debts, see J. HETLAND, supra note 4, § 6.12, at 245-48.

110. Security Pac. Nat'l Bank v. Wozab, 51 Cal. 3d 991, 999, 800 P.2d 557, 562, 275 Cal. Rptr. 201, 206 (1990); Gnarini v. Swiss Am. Bank, 162 Cal. 181, 184, 121 P. 726, 727-28 (1912); McKean v. German-American Sav. Bank, 118 Cal. 334, 340-41, 50 P. 656, 659 (1897); Bank of Am. v. Daily, 152 Cal. App. 3d 767, 771-72, 199 Cal. Rptr. 557, 558-59 (1984); Woodruff v. California Republic Bank, 75 Cal. App. 3d 108, 110, 141 Cal. Rptr. 915, 916 (1977).

In general, absent a violation of $\S 726$, a bank may

take monies or other things of value on deposit in satisfaction of a matured obligation owed by the borrower to the bank. Where money on deposit is at issue, the bank has access to 
term "action" as used in section 726, which is defined at section 22 as "an ordinary proceeding in a court of justice by which one party prosecutes another for the declaration, enforcement or protection of a right." 111 Some cases have held that a banker's setoff is an action or the equivalent of an action for the purposes of section $726,{ }^{112}$ while the holdings of other cases have suggested that even though not technically an action, a banker's setoff violates the security-first principle of the oneaction rule. ${ }^{113}$

In Security Pacific National Bank v. Wozab the Supreme Court of California put the matter to rest by holding that a banker's setoff was not an action for the purposes of section 22 or section $726 .{ }^{114}$ The court recognized, however, that allowing a bank to unilaterally set off a depositor's account in order to satisfy part of a debt secured by real property before foreclosing on the security would undermine the security-first primciple of the one-action rule. Consequently, the Wozab court held that although the setoff was not an action for the purposes of section 726, it was a violation of the security-first primciple embodied in the oneaction rule and, therefore, the bank should be sanctioned for violating section $726 .{ }^{115}$ This holding prevents a bank from obtaining, and simultaneously enforcing, a nonjudicial "personal judgment" against the debtor by unilaterally, and without notice, seizing the debtor's unencumbered assets held by the bank.

The Wozab court was silent with regard to the hotly debated issue of whether California's counterclaim ${ }^{116}$ and setoff ${ }^{117}$ statutes permit a bank to set off a depositor's account to reduce an obligation despite the existence of real property security and section 726 . The dispute originated

the funds via an equitable right of setoff, that is, a right to [set off] the account owed to the depositor in payment or partial payment of the obligation owed to the bank.

Stillman, supra note 12 , at 10 .

111. Cal. Civ. Proc. Code $\S 22$ (West 1991).

112. Daily, 152 Cal. App. 3d at 771-72, 199 Cal. Rptr. at 558-59; McKean, 118 Cal. at 340-41, 50 P. at 659; see also Munoz \& Rabin, supra note 11, at 206 ("[T] he courts in McKean and Daily found that the creditor's conduct violated the one action rule and constituted an 'action' for purposes of § 726.”). But see Wozab, 51 Cal. 3d at 999 \& n.7, 800 P.2d at 562 n.7, 275 Cal. Rptr. at 206 n.7 (stating that McKean did not hold that a setoff is the equivalent of a judicial action for the purposes of $\S \$ 22$ or 726 ).

113. Gnarini, 162 Cal. at 184, 121 P. at 727-28; Woodruff, 75 Cal. App. 3d at 110, $141 \mathrm{Cal}$. Rptr. at 916; see also Munoz \& Rabin, supra note 11, at 206 (Some "supreme court decisions [have] held that the creditor's conduct, in faiting to exhaust the real property collateral first, was contrary to the mandate of $\$ 726$ and so resulted in the waiver of the collateral because the conduct had frustrated the protection of $\S 726$ and the restrictions on collecting a deficiency.").

114. Wozab, 51 Cal. 3d at 998-99, 800 P.2d at 560-61, 275 Cal. Rptr. at 204-05.

115. Id. at 999-1000, 800 P.2d at 561-62, $275 \mathrm{Cal}$. Rptr. at 205-06. The Wozab court's holding that an improper banker's setoff violates the security-first principle has much support from commentators and authorities on California law. See, e.g., R. BERNHARDT, supra note 3, at 189-90; Arnold, supra note 11, at 10-11; Munoz \& Rabin, supra note 11, at 206-07.

116. CAl. CIv. Proc. CoDE $\S \S 428.10$ (West 1991) (formerly $\S 438$ ).

117. Id. $\S 431.70$ (formerly $\S 440$ ). 
almost 100 years ago with McKean v. German-American Savings Bank. ${ }^{118}$ In McKean the assignee of a bank account brought an action against a bank to recover funds deposited by the assignor of the account. Prior to the assignment of the account, the bank had apphed the deposit to reduce a debt of the assignor that was secured by real property. ${ }^{119}$ The bank argued that section 438 permitted it to set off the depositor's account despite the real property security. ${ }^{120}$ The supreme court rejected this argument and held that section 726 barred the setoff. ${ }^{121}$ In 1927 the legislature amended section 438, arguably to overrule McKean. ${ }^{122}$ As amended, section 438 provided for the maintaining of a counterclaim despite the existence of real property security ${ }^{123}$ and arguably had the effect of allowimg a bank to set off a debtor's account under section 440 despite the existence of real property security. ${ }^{124}$ In fact, since the amendment, two cases have imphed that a bank has a right of setoff under sections 438 and 440 despite the existence of real property security and despite section $726 .^{125}$

Several more recent cases, including Wozab, have assumed with little or no argument that section 726 , not section 428.10 (the successor of

118. 118 Cal. 334, 50 P. 656 (1897).

119. Id. at $334,50 \mathrm{P}$. at 657 .

120. Id. at $337-41,50 \mathrm{P}$. at $658-59$.

121. Id. at 118 Cal. at 341,50 P. at 659; accord Gnarini v. Swiss Am. Bank, 162 Cal. 181, 184, 121 P. 726, 727-28 (1912) (relying on McKean and holding that the setoff was barred under the security-first principle).

122. See Munoz \& Rabin, supra note 11, at 208 (citing Nelson v. Bank of America, 76 Cal. App. 2d 501, 173 P.2d 332 (1946)).

123. As amended, $\S 438$ provided that "the right to maintain a counterclaim shall not be affected by the fact that either plaintiff's or defendant's claim is secured by mortgage or otherwise, nor by the fact that the action is brought, or the counterclaim maintained, for the foreclosure of such security." Note, Banks and Banking: Right of Set-Off Against Secured Loan to Depositor, 35 CAL1F. L. REv. 118, 119 n.6 (1947) (authored by J. Taber).

124. "McKean had previously held that setoff's would be allowed under fonner CCP $\S 440$ whenever counterclaims were allowed under CCP $\S 438$. Because the 1927 amendment to $\S 438$ allowed counterclaims involving secured and unsecured debts, it is apparent that setoffs under former $\S 440$, involving secured and unsecured claims, were also permitted." Munoz \& Rabin, supra note 11, at 208 (citation omitted); see also Rowan \& Mertens, supra note 11, at 75 ("It has been suggested that the 1927 amendment to CCP $\S 438$ impliedly amended CCP $\S 440$ as well, thus allowing the setoff of a secured debt."); Comment, supra note 123, at 120 ("It would appear ... that a bank's right of set-off is not limited by section 726."). But see Comment, Mortgages and Trust Deeds: When Foreclosure is Required Under Cal. Code Civ. Proc. $\S$ 726: Counterclaim and Set Off When One Claim is Secured, 25 CALIF. L. Rev. 347, 357 (1937) (authored by Charles L. Hemmings) ("The section [\$ 438] clearly allows an action for foreclosure to be made the subject of a counterclaim, but it is not so certain that the amendment was meant to allow a counterclaim without foreclosure.").

125. Walters v. Bank of Am. Nat'1 Trust \& Sav. Ass'n, 9 Cal. 2d 46, 54, 69 P.2d 839, 842-43 (1937) (assuming arguendo that the bank was entitled to set off the debtor's account "even though the note was secured and without first exhausting the security"); Nelson v. Bank of Am. Nat'1 Trust \& Sav. Ass'n, 76 Cal. App. 2d 501, 510, 173 P.2d 322, 327 (1946) ("[S]ince the amendment of [\$ 438], the bank has a right to set up as a counterclaim the customer's debt to the bank, regardless of whether it is secured by mortgage or not."). 
section 438), controls the appropriateness of a setoff. ${ }^{126}$ For example, the court in Woodruff v. California Republic Bank ${ }^{127}$ held that the right to a setoff found in section 431.70 (formerly section 440) "presumes a lawful and proper [setoff], which in this case can only arise after a judgment of foreclosure has been procured and a deficiency judgment entered." 128 Thus, the court viewed the one-action rule as a rule of substantive law that could not be undermined by a procedural statute.

In deciding Wozab the California Supreme Court failed to address this issue, although it was argued by the parties at the appellate level. ${ }^{129}$ The only reference to this issue in Wozab is indicative of the supreme court's behief that a bank can no longer argue that the 1927 amendment allows banks to set off a debtor's account despite the existence of real property security: "We also note the record before us does not indicate that the prohibition of bank setoff against a secured debt has caused significant problems for the banking industry." 130

Having settled the issue of whether an improper banker's setoff violated section 726, the court in Wozab then turned to the scope of the sanction issue. The court had to choose from at least three alternatives. $^{131}$ The first alternative was the remedy granted by the courts in McKean v. German-American Savings Bank, ${ }^{132}$ Gnarini v. Swiss American Bank, ${ }^{133}$ and Woodruff v. California Republic Bank. ${ }^{134}$ In those cases, the debtors sought recovery of deposits improperly set off in viola-

126. Security Pac. Nat'l Bank v. Wozab, 51 Cal. 3d 991, 996-1000, 800 P.2d 557, 559-62, 275 Cal. Rptr. 201, 203-06 (1990); Bank of America v. Daily, 152 Cal. App. 3d 767, 771-72, 199 Cal. Rptr. 557, 558-59 (1984); Woodruff v. California Republic Bank, 75 Cal. App. 3d 108, 111, 141 Cal. Rptr. 915, 916 (1977); see also Aplanalp v. Forte, 225 Cal. App. 3d 609, 615-17, 275 Cal. Rptr. 144 (1990) (holding that where the sellers of a mobile home park obtained an order to enforce their equitable right to set off a money judgment owed to the purchasers against delinquent payments owed by the purchasers on a note secured by a deed of trust, $\S 726$, and not $\S \S 428.10$ and 431.70 , controlled the appropriateness of the setoff).

127. 75 Cal. App. 3d 108, 141 Cal. Rptr. 915 (1977).

128. Id. at 111, $141 \mathrm{Cal}$. Rptr. at 916.

129. Security Pac. Nat'l Bank v. Wozab, 223 Cal. App. 3d 1042, 1052-53, 258 Cal. Rptr. 850, 854-55 (1989), rev'd, 51 Cal. 3d 991, 800 P.2d 557, 275 Cal. Rptr. 201 (1990).

130. Security Pac. Nat'l Bank v. Wozab, 51 Cal. 3d 991, 1000, 800 P.2d 557, 562, 275 Cal. Rptr. 201,206 (1990). Further support for the argument that $\S 726$ is dispositive when in conflict with the procedural counterclaim and setoff statutes is "the omission in CCP $\S 428.10$ [formerly $\S 438$ ] of the proviso in CCP $\S 438$ that 'the right to maintain a counterclaim shall not be affected by the fact that either plaintiff's or defendant's claim is secured by mortgage or otherwise.'" Rowan \& Mertens, supra note 11, at 75. However, commentators have pointed to the Legislative Committee Comment in West's Annotated California Codes in arguing that the new procedural sections, despite any omissions, were meant to "continue the law under former $\S \S 438$ and 440 for the most part [and] to further liberalize the rules permitting cross-claims and setoffs." Munoz \& Rabin, supra note 11, at 209; see Rowan \& Mertens, supra note 11, at 75.

131. Wozab, 51 Cal. 3d at 1000-01, 800 P.2d at 562, 275 Cal. Rptr. at 206.

132. $118 \mathrm{Cal} .334,334,341,50$ P. $656,657,659$ (1897).

133. 162 Cal. $181,184,121$ P. $726,727-28$ (1912).

134. 75 Cal. App. 3d 108, 110, 141 Cal. Rptr. 915, 916 (1977). 
tion of section 726 and prevailed, while the enforceability of the security and the underlying debt was unaffected. ${ }^{135}$ The second of the alternatives was the loss-of-security sanction. This sanction had never been imposed in an improper banker's setoff case, but was effectively adopted by the Wozab court as the proper sanction under the particular facts of that case. ${ }^{136}$ The third alternative was the combined loss-of-security and loss-of-debt sanction imposed by the California Courts of Appeal in Bank of America v. Daily ${ }^{137}$ and Security Pacific National Bank v.

135. Munoz \& Rabin, supra note 11, at 210. The court in Wozab explicitly addressed and rejected this alternative. Wozab, $51 \mathrm{Cal}$. 3d at 1002, 800 P.2d at 563-64, $275 \mathrm{Cal}$. Rptr. at 207-08. However, elsewhere in the opinion the court suggested that if a bank promptly returns improperly seized funds, no further sanction, other than liability for compensatory damages, should be imposed. Id. at $1001 \mathrm{n} .8,1006,800$ P.2d at $563 \mathrm{n.8}, 566,275$ Cal. Rptr. at $207 \mathrm{n.8}, 210$.

136. Id. at 1001-02, 1004, 800 P.2d at 563-65, 275 Cal. Rptr. at 207-09. Curiously, the court in Wozab never lield that the bank waived its security interest. The issue of whether the bank had waived its security interest was considered moot because prior to the filing of the case the bank had voluntarily reconveyed the security interest upon the Wozabs' request. Id. at 1001,800 P.2d at 563, $275 \mathrm{Cal}$. Rptr. at 207. However, the court indicated that, but for the reconveyance, it would have imposed the loss-of-security sanction because "a creditor bank that violates section 726(a) by taking an improper extrajudicial setoff must be held to have waived the bank's security interest in its depositor's real property." Id. at 1001-02, 800 P.2d at 563, 275 Cal. Rptr. at 207.

137. 152 Cal. App. 3d 767, 199 Cal. Rptr. 557 (1984). Altlough not readily clear from the holding, the Daily court's rehance on Professor Hetland's treatise and the procedural disposition of the appeal indicated that the sanction imposed included loss of the debt. Id. at 771-72, 774, $199 \mathrm{Cal}$. Rptr. at 558-60; Amold, supra note 11, at 3; Hirsch, supra note 11, at 48-49; Weiner \& Tramz, supra note 11 , at 3 .

In Daily, the trial court judgment was a standard form foreclosure judgment for the full amount of the debt with an order to sell the property security, the court reserving jurisdiction to determine the amount of the deficiency upon proper inotion after the foreclosure sale, all as mandated by West's Ann.Cal.C.C.P. $\$ \$ 726 a, 726 b$. The appellate court in Daily reversed this judgment with instructions to the trial court to enter judgment in favor of the Dailys.

R. Maxwell, S. Riesenfeld, J. Hetland \& W. Warren, California Cases on Secured Transactions IN LAND 287 (4th ed. 1991). By holding that the setoff was an action for the purposes of $\S 726$, Daily, $152 \mathrm{Cal}$. App. 3d at 771-72, $199 \mathrm{Cal}$. Rptr. at 559, and by reversing the decree of foreclosure issued by the trial court, id. at 774, $199 \mathrm{Cal}$. Rptr. at 560, the appellate court destroyed the bank's ability to collect on the debt. The one-action rule's prohibition of a second action on a single debt would have barred an action direetly on the note or a private trustee's sale to foreclose on the deed of trust.

The Supreme Court of California badly misconstrued both the result in Daily and the operation of $\$ 726$ in Security Pac. Nat’1 Bank v. Wozab, 51 Cal. 3d 991, 800 P.2d 557, 275 Cal. Rptr. 201 (1990). In responding to the Wozabs' argument that Daily was dispositive, the Wozab court stated that "the [Daily] court did not have occasion to decide whether the bank was precluded frou" pursuing the underlying debt despite its waiver of the security. Id. at 1003,800 P.2d at 564, $275 \mathrm{Cal}$. Rptr. at 208. However, as noted above, the one-action rule's prohibition of multiplc actions for a single debt clearly "precluded" the bank from ever collecting on the debt.

The court then discarded Daily as irrelevant to tlie issue of whether the sanction should include loss of the debt: "The cause of action in Daily was for foreclosure of the bank's security interest. Unlike in the present case, the bank was not seeking to recover on the debt." Id. This statement demonstrates a misunderstanding of the nature of judicial foreclosurc in California. In a lien-theory state like California, real property security is held only to satisfy the underlying debt upon the default of the debtor. See J. Hetland, Secured Real Estate Transactions 65-66 (1974). Therefore, a judicial foreclosure under $\$ 726$ is necessarily an action on the debt. In fact, if an action 
Wozab. ${ }^{138}$ These decisions play a large role in the scope-of-the-sanction controversy because they are the only two cases that have held the harsher sanction to be apphicable in the context of an improper banker's setoff.

In Daily a bank set off the amount of accrued interest due on a delinquent loan secured by a deed of trust froin the checking account of the debtor prior to foreclosing on the deed of trust. ${ }^{139}$ The court held that the setoff was an action for the recovery of a debt within the meaning of section 726 and, therefore, that the bank waived its rights to the security. ${ }^{140}$ Furthermore, the court's disposition of the case rendered the underlying obligation unenforceable. ${ }^{141}$ The harsliness of the sanction imposed was deeined necessary to uphold the protections afforded to mortgagors under California's statutory antideficiency scheme. ${ }^{142}$

Despite the available doctrinal support for the result, ${ }^{143}$ the Daily court's sanction analysis was woefully deficient. It rehied on McKean, Walker, and an excerpt from Professor Hetland's authoritative 1970 treatise. ${ }^{144}$ The court's use of these authorities hardly supported imposition of the more severe sanction. McKean merely held that the debtor could recover the amount improperly set off. ${ }^{145}$ Walker held that the sanction to be imposed when a creditor obtains a judgment on the full amount of the debt in a judicial foreclosure action prior to exhausting all security is loss of the security. ${ }^{146}$ Finally, Professor Hetland's treatise

to judicially foreclose on a real property security interest is not considered an action to recover on the debt, the one-action rule would be ineaningless because a multiply secured mortgagec could bring successive actions for judicial foreclosure with impunity.

138. 223 Cal. App. 3d 1042, 1056-57, 258 Cal. Rptr. 850, 857-58 (1989), rev'd, 51 Cal. 3d 991, 800 P.2d 557, 275 Cal. Rptr. 201 (1990).

139. Daily, $152 \mathrm{Cal}$. App. 3d at 770, $199 \mathrm{Cal}$. Rptr. at 558.

140. Id. at 772-74, $199 \mathrm{Cal}$. Rptr. at 559-60. Of course, the court could have simply held that the setoff was a violation of the security-first principle instead of holding that the setoff was an action for the purposes of $\$ 726$. Rowan \& Mertens, supra note 11 , at 76 ; supra notes $113-15$ and accoinpanying text.

141. See supra note 137.

142. Daily, 152 Cal. App. 3d at 773, 199 Cal. Rptr. at 560; see also Woodruff v. California Repubhic Bank, 75 Cal. App. 3d 108, 111, 141 Cal. Rptr. 915, 917 (1977) ("Under California law, ¿... the creditor must rely upon his security before enforcing the debt. (Code Civ. Proc., \$\$ 580a, 725a, 726.) If the security is insufficient, his right to a judgment against the debtor for the deficiency may be limited or barred by sections $580 \mathrm{a}, 580 \mathrm{~b}, 580 \mathrm{~d}$, or 726 of the Code of Civil Procedure." " (quoting Roseleaf Corp. v. Chierighino, 59 Cal. 2d 35, 38-39, 378 P.2d 97, 98, 27 Cal. Rptr. 873, 874 (1963))); Arnold, supra note 11, at 11 (Both Daily and Woodruff "rely on the concept that the "fair value' limits of Section 726, or the absolute prohibition on deficiency judgments after a trustee's sale codified in CCP $\S 580 \mathrm{~d}$ might bar any recovery of a deficiency judgment altogether following a creditor's exhaustion of its collateral.").

143. See infra Parts V.B. \& VI.

144. Daily, 152 Cal. App. 3d at 771-73, 199 Cal. Rptr. at 559-60.

145. See supra notes $132-35$ and accompanying text.

146. See supra notes $105-08$ and accompanying text. This is not to say that Walker could not be used to support the stronger sanction, see infra Part V.B., but only that the court in Daily failed to do so articulately. 
was not directed to the peculiar nuances of the improper banker's setoff cases. $^{147}$

The court of appeal in Wozab was faced with the same issues addressed in Daily. The Wozabs had executed guarantees for loans to their company and later executed a deed of trust on their residence as security for their guarantees. In an effort to reduce losses prior to the company's filing for protection in bankruptcy, the bank set off $\$ 2800$ in the Wozabs' personal accounts against the company's $\$ 976,600$ debt. The Wozabs' attorney then informed the bank that under Daily, by taking the setoff, it waived any claim against the Wozabs under their guarantees. The bank then reconveyed the deed of trust to the Wozabs and filed suit to collect on the underlying debt. ${ }^{148}$

The court, relying on Daily and citing to Ould v. Stoddard ${ }^{149}$ and Commercial Bank v. Kershner, ${ }^{150}$ held that an improper banker's setoff should result in loss of the security and of the underlying debt. ${ }^{151}$ Both Ould and Kershner are distmguishable from Wozab. In Ould the court stated "that by prosecuting an action upon the note secured by the mortgage to final judgment, the plaintiff has exhausted his reinedy upon both the note and the security."152 Ould, unlike Wozab, involved a creditor who obtained a personal judgment against the debtor and then sought to foreclose on the mortgage securing the debt. The court held that the creditor had elected to bring an action on the note in contravention of section 726 and had, therefore, waived his right to foreclose on the mortgage. ${ }^{153}$ In other words, because the creditor elected to sue on the note in lieu of bringing an action for foreclosure, the creditor's claim was deemed to be satisfied by the judgment on the note. Similarly, the court in Kershner noted that when a creditor obtained a personal judgment in an attachment suit and enforced it on execution, "such proceedings

147. Professor Hetland's discussion of the loss of security and loss of debt sanction focused on a multiple-security situation where the creditor fails to foreclose on all of the security in a singlc foreclosure action. See J. HeTLAND, supra note $4, \S 6.18$, at 257-60. In such a case it is apparent that the creditor would be unable to pursue the amount owing on the debt (because the bank may not have a second action on the debt) or the unforeclosed security (because there would be no debt left to be secured).

However, in the case of an improper banker's setoff, the one-action rule is violated not because the creditor has already had an action (the statutory definition of an action is an ordinary judicial proceeding), but because the setoff violates the security-first principle, which requires the exhaustion of all security prior to the availability of a deficiency judgment against the debtor. It is not so apparent what the sanction should be in this situation. See infra Part V.D.

148. Security Pac. Nat'l Bank v. Wozab, 223 Cal. App. 3d 1042, 1045-46, 258 Cal. Rptr. 850, 850-51 (1989), rev'd, 51 Cal. 3d 991, 275 Cal. Rptr. 201, 800 P.2d 557 (1990).

149. $54 \mathrm{Cal} .613$ (1880).

150. $120 \mathrm{Cal} .495,52$ P. 848 (1898).

151. Wozab, 223 Cal. App. 3d at 1056-57, 258 Cal. Rptr. at 858.

152. Ould, 54 Cal. at 615.

153. Id. 
amounted to a waiver of the right to foreclose."154 Thus, both Ould and Kershner involved a creditor that elected to sue directly on the debt instead of bringing a foreclosure action as required under section 726 and, therefore, the sanction imposed was loss of the security. In contrast, Wozab involved a creditor that, by choosing the self-help remedy of setoff, effectively obtained, and simultaneously enforced, a nonjudicial personal judginent representing only a fraction of the entire debt.

In referring to the appellate court opinion in Wozab, and prior to the supreme court's decision in Wozab, one commentator noted that "[o]ther courts are likely to find a more appropriate sanction than loss of the entire amount of a legitimate claim when an unpaid creditor has inadvertently taken an asset out of order."15s The supreme court heeded this advice in Wozab, but it did so carelessly.

\section{$\mathrm{V}$ \\ The Wozab Opinion-Careless Application of ONe- ACTION RULE DOCTRINE}

The California Supreme Court neatly disposed of two biting issues in Wozab. First, the court held that a setoff was not an action as described in section 22 and was, therefore, not an action under section 726. ${ }^{156}$ Second, despite the extensive discussion by the court of appeal about the relationship between section 726 and California's counterclaim $^{157}$ and setoff ${ }^{158}$ statutes, the supreme court ignored the issue, allowing section 726 to trump the other statutes. ${ }^{159}$ Unfortunately, the court only deepened the scope of the sanction controversy through careless application of one-action rule doctrine. ${ }^{160}$

\section{A. Careless Language}

The court began its analysis of the sanction controversy by noting that a creditor who sues only on the underlying debt waives the secur-

154. Kershner, $120 \mathrm{Cal}$. at $498-99,52$ P. at 850.

155. R. BERNHARDT, supra note $3, \S 4.5$, at 190 . It should be noted, however, that the setoff by the bank in Wozab was meant to reduce losses from an impending bankruptcy filing and, therefore, was less than "inadvertent." See Wozab, 223 Cal. App. 3d at 1045-46, 258 Cal. Rptr. at 851.

156. Security Pac. Nat'1 Bank v. Wozab, 51 Cal. 3d 991, 998, 800 P.2d 557, 560-61, 275 Cal. Rptr. 201, 204-05 (1990).

157. Cal. Clv. Proc. Code $\S \S 428.10$ (West 1991) (formerly $\S 438$ ).

158. Id. $\S 431.70$ (West 1991) (formerly § 440).

159. See supra text accoinpanying notes 114-30.

160. Many of the ideas for Part V of this Comment were presented and discussed in Professor Hetland's Real Property Secured Transactions course. He deserves full credit for revealing the inadequacies of the Wozab opinion. See R. MAXWELL, S. Riesenfeld, J. HeTLAND \& W. WARREN, supra note 137, at 286-89 (4th ed. 1991). 
ity. ${ }^{161}$ This is an accurate statement of the law. ${ }^{162}$ The court then compared these facts with the situation in which "a creditor has multiple security mterests for a debt and proceeds agamst less than all of them in a judicial foreclosure action, in which he obtains a deficiency judgment."163 The court stated that in such circuinstances the security is waived but the debt reinains "unaffected." 164 Although the court's assertion would be an accurate statement of the law under the rule of Walker v. Community $B a n k^{165}$ if the creditor sued for the entire debt, foreclosed on some of the security, and obtained a deficiency judgment for the amount owing on the entire debt following the foreclosure sale, the court's language was not so precise.

The significance of this carelessness is apparent when a creditor in the situation described by the court forecloses on only part of the security without sumg for the full amount of the debt. If the debtor fails to raise the one-action rule affirmative defense, and the creditor obtams a personal deficiency judgment representing the amount owing on the part of the debt sued on, the creditor may not recover any ainount owing on the debt other than the judgment obtained or foreclose on any omitted seeurity. The creditor has already expended its one action and may not sue again; the portion of the debt not sued upon is forever lost.

\section{B. Careless Reasoning}

The court stated that because the setoff of the Wozabs' account was not a judicial action, the bank did not obtain a judgment for the full amount of the debt, or a deficiency judgment representing the amount owing on the debt, in exercising the setoff. ${ }^{166}$ Accordingly, the court reasoned that under Walker and Salter v. Ulrich" 167 the bank "must be allowed to seek a judgment for the full balance of the debt."168 In Walker, however, the bank did have a deficiency judgment representing the ainount owing on the entire debt, ${ }^{169}$ and in Salter the creditor did have a personal judgment for the full amount of the debt. ${ }^{170}$ If the bank in Walker or the creditor in Salter had not had some type of judgment representing the full debt, they would have been precluded froin bringing another action on either the security or the debt to satisfy the amount

161. Wozab, 51 Cal. 3d at 1004, 800 P.2d at 565, 275 Cal. Rptr. at 209.

162. See supra Part III.A.

163. Wozab, 51 Cal. 3d at 1004, 800 P.2d at 565, 275 Cal. Rptr. at 209.

164. Id.

165. $10 \mathrm{Cal} .3 \mathrm{~d} 729,518$ P.2d 329, $111 \mathrm{Cal}$. Rptr. 897 (1974); see supra text accompanying notes 84-85, $105-08$.

166. Wozab, $51 \mathrm{Cal} .3 \mathrm{~d}$ at 1004, 800 P.2d at 565, 275 Cal. Rptr. at 209.

167. 22 Cal. 2d 263, 138 P.2d 7 (1943).

168. Wozab, 51 Cal. 3d at 1004, 800 P.2d at 565, 275 Cal. Rptr. at 209.

169. Walker, 10 Cal. $3 d$ at 732,518 P.2d at 331, 111 Cal. Rptr. at 899 .

170. Salter, $22 \mathrm{Cal} .2 \mathrm{~d}$ at 265,138 P.2d at 8. 
owing on the debt. ${ }^{171}$ The situation in both Walker and Salter-a debtor failing to raise the one-action rule affirmative defense and a creditor obtaining a judgment for the full amount of the debt-is fundainentally different from the situation in Wozab, in which the bank effectively obtained, and simultaneously enforced, a nonjudicial personal judgment representing only a fraction of the entire debt. ${ }^{172}$ Thus, the supreme court in Wozab was hardly justified in citing Walker and Salter as support for imposing the loss-of-security-only sanction.

Perhaps the court intended to argue that because the setoff was not technically an action for the purposes of section 726 , the setoff was a nullity and therefore had no effect on the bank's ability to bring a judicial action on the debt. Yet, this reasoning would conflict with the court's holding that the setoff violated the security-first principle of the oneaction rule and that the proper sanction was loss of the security. ${ }^{173}$

By holding that the setoff was a violation of the security-first principle, it follows that the court viewed the setoff as behavior just as condeinnable as a judicial action achieving the same purpose. After all, if the bank had brought a judicial action to appropriate the funds in the Wozabs' bank account without suing for the full amount of the debt and had obtained a judgment allowing the seizure of the funds and executed the judgment, the bank would have been unable to pursue either the amount owing on the debt (because the bank would not have been able to bring a second action on the debt) or the unforeclosed-on security (because there would have been no debt left to be secured). ${ }^{174}$ In other words, if the bank had proceeded by judicial action, the coinbined lossof-security and loss-of-debt sanction would have applied.

However, ratlier than subjecting the bank to the stronger sanction, the supreme court simply indicated that the bank liad waived its security interest, leaving the debt intact. Thus, the court seemed to argue that because a banker's setoff is not technically an action for the purposes of section 726 , it is a less serious infraction of the one-action rule than aclieving the saine result through judicial ineans.

171. See supra Part III.B.

172. Wozab, 51 Cal. 3d at 1015, 800 P.2d at 572, 275 Cal. Rptr. at 216 (Broussard, J., concurring and dissenting).

173. Id. at 999,800 P.2d at 562, 275 Cal. Rptr. at 206.

174. Just as the bank would clearly be barred from bringing a second action to collect the remainder of the debt if it had obtained the proceeds of the debtor's bank account through an initial judicial action against the debtor, the bank should similarly be barred from seeking additional recovery froin the debtor when, without exhausting the security, it inproperly seized nonsecured property without the debtor's consent through its unilateral extrajudicial conduct.

Id. at 1015, 800 P.2d at 572, $275 \mathrm{Cal}$. Rptr. at 216 (Broussard, J., concurring and dissenting). 


\section{Careless Equities}

The Wozab court was guilty not only of careless language and reasoning, but also of distorting the facts of the case in a inanner favorable to the bank in order to justify its holding. The court stated that the Wozabs "voluntarily relinquished" their rights under section 726 by accepting the reconveyance of the deed of trust and engaged in "gamesinanship" by later asserting their rights under the statute. ${ }^{175}$ As the dissent pointed out,

[w] hen the debtor, after discovering the setoff, took the legal position that the bank's misconduct had resulted in the bank's loss of both its security interest and the balance of the underlying debt, the debtor was relying on the holding and reasoning of the only judicial authority on point-Bank of America v. Daily . . . . It was in light of the Daily decision that the bank voluntarily agreed to reconvey the secured property to the debtor, and then filed this action to attempt to himit the scope of the Daily decision. ${ }^{176}$

In other words, the only reason that the Wozabs accepted reconveyance of the deed of trust was that they knew, as did the bank, that under Bank of America v. Daily ${ }^{177}$ the sanction for an improper banker's setoff was at least loss of the creditor's rights in the security. ${ }^{178}$ This undisputed fact was halfheartedly acknowledged by the majority: "[W]e think it important to note that the bank's voluntary reconveyance was an accurate reflection (and perhaps imphicit acknowledgment by the bank) of the long-estabhished rule as to the effect of an improper setoff."179

Thus, in order to support its holding that the coinbined loss-ofsecurity and loss-of-debt sanction should not be imposed on the bank, the supreme court in Wozab inaccurately portrayed the bank as naive and the Wozabs as condemnably crafty. Although the imposition of the stronger sanction seems unfair under the extraordinary facts presented in $W o z a b$, the court should have based its holding on sound interpretation of one-action rule doctrine or should have explamed why the particular facts of the case warranted a holding inimical to current legal doctrine. What the court should not have done, of course, was distort the facts in an atteinpt to legitimize its holding. ${ }^{180}$

175. Id. at 1005,800 P.2d at 565-66, 275 Cal. Rptr. at 209-10.

176. Id. at 1015 n.4, 800 P.2d 572 n.4, 275 Cal. Rptr. at 217 n.4 (Broussard, J., concurring and dissenting).

177. 152 Cal. App. 3d 767, 772-74, 199 Cal. Rptr. 557, 559-60 (1984).

178. Wozab, $51 \mathrm{Cal}$. 3d at 996, 800 P.2d at 559, 275 Cal. Rptr. at 203.

179. Id. at $1001,800 \mathrm{P} .2 \mathrm{~d}$ at 563, $275 \mathrm{Cal}$. Rptr. at 207.

180. The political makeup of the court that decided Wozab provides some insight into its "inequitable" treatment of the Wozabs:

Five of California's seven Supreme Court justices, all distinguished career jurists, had been appointed by California's fiscally conservative ex-governor, Republican George Deukmejian. The four justices voting with the majority in Wozab were all Deukmejian 


\section{Careless Dicta}

The main question before the court in Wozab was whether the proper sanction under section 726 for an improper banker's setoff should be loss of the security, or alternatively loss of the security and loss of the underlying debt. The sanction effectively imposed by the court was loss of the security only. ${ }^{181}$ As noted earher, the reasoning employed by the court in choosing this sanction, as opposed to a combined loss-of-security and loss-of-debt sanction, was questionable because the court's analysis turned on the technical definition of an action. ${ }^{182}$ It is understandable that the court settled on a middle ground when faced with extraordinary facts and a controversial doctrine that was virtually inapphicable to the transaction at issue. What is not understandable was the court's suggestion, in dicta, that the combined sanction or no sanction at all would be appropriate given different facts.

The court considered four different fact scenarios in its sanction analysis. It first confronted the facts presented in Wozab: a bank intentionally sets off a debtor's unencumbered account, the debtor does not ask for a return of the funds set off, and the creditor keeps the funds. ${ }^{183}$ In considering the proper sanction to impose under these facts the court noted that the issue of whether the bank had waived its right to foreclose on the security was mooted by the reconveyance of the deed of trnst at the request of the Wozabs prior to suit. ${ }^{184}$ However, so as not to render the case meaningless as precedent, the court, relying on Walker and Daily, stated that absent the reconveyance, the proper sanction to impose would have been loss of the security. ${ }^{185}$

The court next considered the scenario in which a bank inadvertently sets off a debtor's unencumbered account, but promptly and unilaterally returns the funds set off. ${ }^{186}$ Carefully noting that this issue was not presented under the facts of the case, the court argued that imposing a sanction would be unduly harsh and that the appropriate remedy might be to hold the bank hable for compensatory damages. ${ }^{187}$ Careful consid-

appointees and registered Republicans. The three voting against were the court's two Democrats, and its sole declines-to-state, Hon. Joyce L. Kennard.

Stillman, supra note 12 , at 10.

181. Wozab. 51 Cal. 3d at 1001-02, 1004, 800 P.2d at 563, 565, 275 Cal. Rptr. at 207, 209; see supra note 136.

182. See supra Part V.B.

183. Wozab, 51 Cal. 3d at 1001, 800 P.2d at 563, 275 Cal. Rptr. at 207.

184. Id.

185. Id. at 1001-02, 800 P.2d at 563, $275 \mathrm{Cal}$. Rptr at 207.

186. Id. at $1001 \mathrm{n} .8,800$ P.2d at 563 n.8, 275 Cal. Rptr. at 207 n. 8 .

187. Id. Curiously, the court rejected this very remedy (return of the setoff and compensatory damages) in its analysis of the proper sanction to impose under the actual facts of the case. The court argued tlrat this reenedy would provide debtors with little economic incentive to bring suit to recover improperly set off funds, would provide attorneys with little incentive to accept such cases, 
eration exposes this approach as untenable for the following reasons.

First, hitigation concerning the appropriate standard for promptness would be inevitable. ${ }^{188}$ Second, hitigation would arise as to whether the setoff was truly a mistake or was an attempt to cut losses in anticipation of bankruptcy proceedings. Third, unless "compensatory damages" refers to interest accrued during the period the funds were seized, some type of legal proceedings would be necessary to determine compensatory damages. ${ }^{189}$ For example, even were the funds taken only for a short while, if the debtor needed those funds to keep from defaulting on another inortgage or to wrap up a business deal in which timie was of the essence, compensatory damages could be very high ${ }^{190}$ and very difficult to ascertain. Therefore, the court's dicta suggesting compensatory damages as an exclusive remedy should be ignored by future courts looking to Wozab for guidance.

The third fact pattern considered by the court was a slight variation of the second: a bank madvertently sets off a debtor's unencumbered account, the debtor objects to the setoff and requests the return of the funds set off, and the creditor complies with the debtor's request. ${ }^{191}$ Agam the court suggested that the fair result would be to require the bank to pay compensatory damages. ${ }^{192}$ As noted above, the remedy of compensatory damages is both impractical and inadequate as an exclusive remedy im improper banker's setoff cases.

The court only worsened matters by suggesting that a debtor in this situation wonld also be able to compel the creditor to proceed against the security: "a debtor can object to an imiproper setoff and require the bank to return it and proceed first agamst the security imterest." 193 This statement by the court contradicted its earlier holding that a setoff is not the equivalent of a judicial action for purposes of section 726. After all, a

and would provide banks with little economic incentive to comply with $\S 726 . I d$. at 1002,800 P.2d at 563-64, $275 \mathrm{Cal}$. Rptr. at 207-08.

The court also argued that forcing debtors to bring suit to reverse improper setoffs would violate the one-action rule's prohibition on a multiplicity of actions because the bank could still bring suit to foreclose on the security. Id. Although it is true that requiring debtors to bring suit to recover improper setoffs would impose a substantial burden on debtors' time and resources, it should be noted that the one-action rule's policy of preventing a multiplicity of actions would not be implicated because the policy is only addressed to actions mitiated by creditors.

The court did not state why these otherwise legitimate objections to a damages remedy as an exclusive remedy do not counsel against imposing the remedy where a bank inadvertently sets off a debtor's unencumbered account but promptly returns the funds.

188. Furthermore, it would be absurd if the degrec of culpability attributed to a misunderstanding of the law or a clerical error depended on the length of time before it was detected.

189. Id. at 1002, 800 P.2d at 563, 275 Cal. Rptr. at 207.

190. Id. at 1011, 800 P.2d at 570, $275 \mathrm{Cal}$. Rptr. at 214 (Broussard J., concurring and dissenting).

191. Id. at 1001 n.8, 800 P.2d at 563 n.8, 275 Cal. Rptr. at 207 n.8.

192. Id.

193. Id. at $1006,800 \mathrm{P} .2 \mathrm{~d}$ at $566,275 \mathrm{Cal}$. Rptr at 210 . 
debtor may raise the one-action rule affirmative defense to compel a creditor to foreclose on all security for a debt only after the creditor has brought an action on the debt. Furthermore, banks could routinely engage in improper setoffs with impunity, knowing that a percentage of the depositors so victimized would not pursue the matter. ${ }^{194}$

Incredibly, the court also provided a scenario under which the combined loss-of-security and loss-of-debt sanction would be appropriate: "Of course, if the bank refused the debtor's demand and retained the setoff funds, the security-first rule . . . wonld preclude the bank from foreclosing the security interest or proceeding on the underlying debt." 195 The carelessness of this dictun hes not $\mathrm{m}$ its legitimacy but im its lack of elaboration. Rather than articulating a doctrimal rationale for imposing the combined loss-of-security and loss-of-debt sanction, the court irresponsibly set forth an arbitrary standard for imposing the stronger sanction - namely, when a bank acts in bad faith by refusing upon the debtor's demands to return funds improperly set off. Thus, the inajority wonld impose the combined sanction as a purely pumitive measure without regard to doctrimal concerns.

Nonetheless, the court's failure to explam the basis for its suggested application of the combimed loss-of-security and loss-of-debt sanction does not undermine the potential legitimacy of applying this sanction in the context of an improper banker's setoff. Consider a situation in which a bank has improperly set off a debtor's account with the knowledge that its position would be much better with the setoff and a personal judgment for the amount owing on the debt than with a decree of foreclosure and a potential personal deficiency judgment. Should the bank be deemed to have waived the security but to have retained an enforceable personal judgment? Clearly not.

With a personal judgment, a creditor, along with all other unsecured creditors of the debtor, must enforce the judgment to obtain any inoney. In contrast, when a bank improperly sets off a debtor's account, it has effectively obtained, and simultaneously enforced, a nonjudicial "personal judgment," depriving the debtor and competing creditors of funds to which the bank inay never be entitled, given the fair value deficiency limitation of section 726(b) (judicial foreclosure sales) and the absolute deficiency bar of section 580d (nonjudicial foreclosure sales). ${ }^{196}$ In other words, this nonjudicial "personal judgment" is a far more serious violation of the security-first primciple than a judicial personal judgment.

194. Id. at 1013, 800 P.2d at 571, 275 Cal. Rptr. at 215 (Broussard, J., concurring and dissenting).

195. Id. at 1006, 800 P.2d at 566, 275 Cal. Rptr. at 210.

196. Id. at 1010, 800 P.2d at 569, $275 \mathrm{Cal}$. Rptr. at 213 (Broussard, J., concurring and dissenting). 
Analogizing to the paradigm case in which the combined loss-of-security and loss-of-debt sanction has been imposed-when a multiply secured creditor omits part of the security froin an action for judicial foreclosure and neglects to sue on the entire amount of the debt-it would seem that the proper sanction to impose when faced with an improper banker's setoff should be loss of that portion of the debt not seized and the consequent loss of all security for that debt.

\section{VI}

\section{A Proposal for a Uniformly Applicable Remedy in IMPROPER BANKER'S SETOFF CASES}

The highly subjective and inescapably ad hoc approach adopted in $W o z a b$ for resolving scope-of-the-sanction hitigation in improper banker's setoff cases creates serious problems for lower courts seeking guidance in interpreting one-action rule sanction doctrine. Legislative reform of section 726-a statute that has remained essentially unchanged since its adoption in $1860^{197}$-is unnecessary. ${ }^{198}$ What is necessary is recognition of a uniformly apphicable reinedy that is firmly grounded in one-action rule doctrine and could be imposed regardless of the culpability of the bank.

Before discussing the proposal, it bears repeating that an honest

197. See Comment, supra note 1 , at 429 ("the first sentence of section 726 which embodies the 'one action' rule has undergone no material change simce its original enactment").

198. Prior to the decision in Wozab, one commentator ambitiously set out to clarify one-action rule sanction doctrine with a proposal to amend $\S 726$. Mertens, supra note 11 , at 577-79. The threc-part proposal suggested (1) incorporating the definition of the term "action" found in $\S 22$ into the language of $\S 726,(2)$ adding a statement of legislative policy so as to codify the security-first principle, and (3) adding a section spelling out the operation of the statute and limiting the sanction for violation of the statute to loss of the security. Id. The first suggested amendment has been inooted by Wozab. See Wozab, 51 Cal. 3d at 998, 800 P.2d at 560-61, 275 Cal. Rptr. at 204-05 (holding that a banker's setoff was not an "action" based on the plain language of $\S 22$ ). The second suggested amendinent, that of codifying the security-first principle, is unnecessary given the judiciary's universal recognition of the principle as a corollary to the one-action rule. See supra Part I.B. Lastly, the third suggested statutory amendment, if enacted, would overturn numerous inultiple-security cases, see, e.g., Stockton Sav. \& Loan Soc'y v. Harrold, 127 Cal. 612, 616-17, 60 P. 165, 167 (1900); Woodward v. Brown, 119 Cal. 283, 292-94, 51 P. 2 (1897); Hall v. Arnott, 80 Cal. 348, 350-51, 22 P. 200, 201 (1889), and at least one equitable setoff case, Aplanalp v. Forte, $225 \mathrm{Cal}$. App. 3d 609, 275 Cal. Rptr. 144 (1990).

In Aplanalp, a ease decided just eight days before the supreme court decided Wozab, the sellers of a mobile home park obtained an order from the trial court to enforce their equitable right of setof of a money judgment owed by the sellers to the purchasers against delinquent payments owed by the purchasers on a note and deed of trust. The court of appeal held the sellers were barred from foreclosing on the note under $\$ 726$. Id. at 612-15, $275 \mathrm{Cal}$. Rptr. at 146-48. Because the debtors sought to quiet title and to cancel the note and deed of trust, id. at $612,275 \mathrm{Cal}$. Rptr. at 146, and the court of appeal reversed the trial court in favor of the purchasers, id. at 617, 275 Cal. Rptr. at 149 , it would appear as though the court imposed a combined loss-of-security and loss-of-debt sanction. See R. MAXwell, S. Riesenfeld, J. Hetland \& W. WARREN, supra note 137, at 293. 95. 
application of section 726 in the context of an improper banker's setoff points to a different result-namely, loss of the security and loss of the underlying debt. ${ }^{199}$ As noted earlier, if tlie bank in Wozab had brought a judicial action to appropriate the funds in the Wozabs' bank account without suing for the full amount of the debt and had obtained a judgment allowing seizure of the funds and executed the judgment, the bank would have achieved the same result as the unilateral seizure of the funds by setoff, but would have been unable to pursue the amount owing on the debt (because the bank would have been barred from bringing a second action on the debt) or the unforeclosed-on security (because tliere would have been no debt left to secure). ${ }^{200}$

Thus, in searching for an answer to the sanction controversy, doctrinal honesty dictates that one analogize to the paradigm case in which the combined loss-of-security and loss-of-debt sanction has been imposed-a multiply secured creditor omits part of the security from an action for judicial foreclosure and neglects to sue on the entire amount of the debt. The court's holding in Wozab eliminated this approach because, according to the court, a setoff is "not an action within the meaning of section 22" and therefore is not an action for judicial foreclosure within the meaning of section $726 .{ }^{201}$ Accordingly, the following proposal is necessarily a second-best solution.

The California Supreme Court in Wozab was faced with the problein of determining the proper sanction to impose on a bank that has violated section 726 by improperly setting off a debtor's account. ${ }^{202}$ Ignoring the values of judicial efficiency and certainty of outcome, the supreine court suggested that the debtor's remedy should vary depending on whether the setoff was intentional or not and whether it was returned proinptly or not at all. ${ }^{203}$ As a result, the scope-of-the-sanction controversy was left unresolved. The following discussion advances a proposal for a single, uniformly applicable remedy in all improper banker's setoff cases-requiring the return of the funds set off, awarding the debtor coinpensatory and perhaps punitive damages, and providing the debtor with the option either to raise the one-action rule affirmative defense or to be excused from liability on the security interest.

This proposal is grounded in part in the law of conversion. When a bank improperly sets off a debtor's unencumbered account to collect on a debt secured by real property, it has committed the tort of conversion. Notwithstanding the potential for section 726 sanction effects, the debtor

199. See supra Part V.B.

200. See supra note 174 and accompanying text.

201. Wozab, 51 Cal. 3d at 998, 800 P.2d at 560-61, 275 Cal. Rptr. at 204-05.

202. See supra text accompanying notes 131-38.

203. See supra Part V.D. 
can always sue for return of the funds set off and for compensatory damages $^{204}$ so as to restore the parties to their respective positions before the setoff.

Although this remedy was not available to the Wozabs because they failed to sue for return of the funds set off, ${ }^{205}$ the majority nonetheless discussed the imphications of adopting such a remedy. Not surprisingly, the court planted another seed of confusion by outright rejection of the remedy as an madequate deterrent, arguing that, as a matter of "commercial reality," a debtor would have a difficult time financing and litigating an action to reverse a setoff. ${ }^{206}$ The court further argued that forcmg the debtor to bring an action to recover the funds set off and then to defend another action for foreclosure under section 726 would confound the purpose of section 726 to prevent a multiphicity of actions. ${ }^{207}$

What each of these criticisms failed to take into account is that the remedy of return of the funds set off and compensatory damages is not an exclusive remedy-rather, it is merely a preliminary remedy to be accompanied by the appropriate section 726 sanction. ${ }^{208}$ The proposed uniformly apphicable remedy recognizes this. Following an improper setoff, the debtor would file a complaint alleging that, under section 726 , the creditor is hable for the tort of conversion and for violating the securityfirst principle. In pleading its remedy, the debtor would first ask for return of the funds set off (if not already returned) and for compensatory damages (including interest). As discussed below, the debtor would then ask the court either to impose the loss-of-security sanction on the creditor, or alternatively to coinpel the creditor to foreclose on all of its security. Thus under the proposed remedy, a debtor would only have to go to court once. Furthernore, given the potential for significant tort damages in addition to a section 726 sanction, creditors would be sufficiently deterred froin improperly exercising their powers of setoff, and debtors

204. Wozab, 51 Cal. 3d at 1011, 800 P.2d at 569-70, 275 Cal. Rptr. at 213-14 (Broussard, J., concurring and dissenting); Stillman, supra note 12, at 10.

205. Wozab, 51 Cal. 3d at 996, 800 P.2d at 559, 275 Cal. Rptr. at 203.

206. Id. at 1002, 800 P.2d at 563-64, $275 \mathrm{Cal}$. Rptr. at 207-08.

207. Id.

208. Id. at 1011, 800 P.2d at 569-70, 275 Cal. Rptr. at 213-14 (Broussard, J., concurring and dissenting); Stillman, supra note 12, at 10.

The majority in Wozab argued that where a bank promptly returns an improper setoff, the creditor should not be subject to the loss-of-security sanction. Wozab, $51 \mathrm{Cal}$. 3d at $1001 \mathrm{n} .8,800$ P.2d at 563 n.8, $275 \mathrm{Cal}$. Rptr. at 207 n.8. Although it is not clear, the majority probably reasoned that once an improper setoff is reversed and compensatory damages awarded, the bank has completely atoned for its violation of the security-first principle. This fails to recognize that the seizure of a debtor's unencumbered assets is a far more serious violation of the security-first principle than a typical violation in which the creditor obtains an unsecured personal judgment and must compete with other unsecured creditors in enforcing its judgment. See supra text accompanying note 196. 
would have sufficient incentive to raise a section 726 claim. ${ }^{209}$

The second part of the proposed uniformly applicable remedy analogizes, in part, to the typical section 726 scenario in which a creditor brings an action on the note. The sanction imposed in this situation is a reduction in the status of the creditor from secured to unsecured, while preserving the enforceability of the personal judgment. ${ }^{210}$ The analogy between this scenario and the improper banker's setoff scenario is based on the fact that, in each case, the creditor demonstrates an intent to resort to the debtor's personal assets. Altliough seeming to fail in hight of the Califorina Supreme Court's holding that a nonjudicial setoff is not an action within the meaning of section 726 , the analogy could be legitimately recognized in section 726 sanction doctrine by allowing a debtor to raise an equitable estoppel defense.

The defense would be simple and powerful. If in the course of a debtor's suit for violation of section 726 the creditor alleges that it can proceed to foreclose on the security interest, the debtor could argue that the creditor is estopped from foreclosing on the security on the grounds that by improperly seizing the debtor's funds in violation of the securityfirst principle, the creditor has demonstrated an intent to resort to the debtor's personal assets. In other words, the creditor would be treated as though it had obtained a final and valid personal judgment on the debt. Althougli this analysis detours froin traditional one-action rule doctrine, it recognizes that the seizure of a debtor's unencumbered assets is a far more serious violation of the security-first principle than a typical violation in whicli the creditor obtains an unsecured personal judgment and must compete witl other unsecured creditors in enforcing its judgment. ${ }^{211}$

As explained thus far, a uniformly applicable remedy should include return of the funds set off, compensatory dainages, and loss of the security. As will be explained below, this remedy is far from complete. What must be addressed at this point is the debtor's right to raise section 726 as an affirmative defense to prevent its unencumbered assets from being seized prior to exhaustion of all security. In addition to the obvious rea-

209. Thus, the proposed uniformly applicable remedy addresses the Wozab majority's concern that compensatory damages as an exclusive remedy would not be a sufficient disincentive for banks to violate $\$ 726$ and would not be a sufficient incentive for debtors to bring suit to recover an improper setoff. Wozab, $51 \mathrm{Cal}$. 3d at 1002, 800 P.2d at 563-64, $275 \mathrm{Cal}$. Rptr. at 207-08. In fact, compensatory damages alone may provide debtors with sufficient imcentive to bring a $\$ 726$ claim. For example, even if the funds were only taken for a short while, if the debtor needed those funds to keep from defaulting on another mortgage or to wrap up a business deal in which time was of the essence, compensatory damages could be very high indeed. See id. at 1011, 800 P.2d at 570, 275 Cal. Rptr. at 214 (Broussard, J., concurring and dissenting) ("[A] debtor may suffer substantial damages as a result of being deprived of the proceeds of a personal bank account.").

210. See supra Part III.A.

211. See supra text accompanying note 196. 
sons why a debtor might want to protect its personal assets by raising the affirmative defense, ${ }^{212}$ there are at least two reasons why a creditor might prefer an unsecured personal judgment over the right to foreclose on a real property security interest. First, if the creditor knows that the debtor is in possession of highly hiquid assets sufficient to cover the debt, the creditor would likely prefer to obtain a personal judgment so that it can levy on the debtor's assets rather than proceed with a time-consuming foreclosure sale. Second, a creditor holding a security interest on a parcel of real property subject to federal environmental cleanup hability under the Coinprehensive Environmental Response, Coinpensation, and Liability Act of 1980 (CERCLA) ${ }^{213}$ would clearly prefer an unsecured personal judgment over becoming a potentially responsible party for a inultimillion-dollar cleanup bill. Thus, imposing a loss-of-security sanction on a creditor without giving the debtor a chance to raise the affirmative defense could, under certain circumstances, create a windfall for the creditor. The proposed uniformly applicable reinedy should give debtors the option either to raise the affirmative defense, or alternatively to ask the court to impose a loss-of-security sanction. ${ }^{214}$

212. See supra text accompanying notes 50-56.

213. 42 U.S.C. $\S \S 9601(20)(A), 9607(a)(1)-(2)$ (1988). CERCLA imposes liability on "owners or operators" of facilities targeted for cleanup by the EPA. A real property secured creditor may be liable as an owner under CERCLA if it forecloses on the contaminated property, purchases the property at the foreclosure sale by entering a credit bid for the amount of the debt, and holds on to the property for a signifieant length of time. See United States v. Maryland Bank \& Trust Co., 632 F. Supp. 573, 579 (D. Md. 1986). Furthennore, a real property secured creditor may be liable as an operator under CERCLA if it is found to have "participat[ed] in the financial management of a facility to a degree indicating a capacity to influence the [debtor's] treatment of hazardous wastes." United States v. Fleet Factors Corp., 901 F.2d 1550, 1557 (11th Cir. 1990), cert. denied, 111 S. C. 752 (1991).

Until recently, a California creditor holding a security interest in contaminated real property was prevented fronı waiving its security interest under $\S 726$. Recently adopted $\S 726.5$ allows such a creditor to waive its security interest in "environmentally impaired" property and proceed against the debtor as an unsecured creditor under certain circumstances. Act of October 14, 1991, ch. 1167, \$ 3, 1991 Cal. Legis. Serv. 4846 (West) (to be codified at CAL. Civ. Proc. CoDE § 726.5) (effective Jan. 1, 1992). Generally, $\S 726.5$ is available to a creditor if: (1) the costs of cleanup exceed $25 \%$ of the fair market value of the real property security, which is determined without considering the effect of the contamination on the value of the property, id. at 4847 (to be codified at CAL. Crv. Proc. CODE § 726.5(e)(3)), and (2) the borrower or an agent of the borrower had actual knowledge of the contamination problen at the time of the creation of the obligation, or the borrower or an agent of the borrower caused, contributed to, or permitted the occurrence of the contamination, id. at 4846 (to be codified at CAL. Civ. Proc. CODE § 726.5(d)). Importantly, although § 726.5 allows a California secured creditor to waive an environmentally impaired and therefore potentially valueless security interest, it does not operate to shield a secured creditor from CERCLA liability under the rules announced in Maryland Bank \& Trust Co. and Fleet Factors.

214. This approach, providing the debtor with an option to raise the affirmative defense or to rely on the sanction, comports with the established, but not completely aceepted, rule that a debtor may elect to waive the affirmative defense and rely instead on the one-action rule sanction. See supra note 57 and accompanying text. It would not be unfair to allow the debtor to nakc this election after the improper setoff has occurred because a unilateral setoff wrongfully deprives the debtor of 
It is necessary to examine how the proposed remedy would respond to the supreme court's suggestion that the sanction should vary in severity depending on whether the setoff was madvertent or intentional. A footnote to the majority opinion suggested that where a bank iniproperly sets off a debtor's bank account inadvertently or due to ignorance of the law, and promptly returns the funds either unilaterally or at the request of the debtor, compensatory damages should be the sole reinedy. ${ }^{215}$ However, as noted earher, this rule would be inipractical. ${ }^{216}$ In addition, imposing a single, uniform remedy, regardless of whether the setoff was an error or not, would be consistent with one-action rule doctrine ${ }^{217}$ and would announce to the banking industry the seriousness of an improper setoff. $^{218}$

The court confirmed its use of a shiding-scale-of-culpability analysis by announcing in the last sentence of the opinion that if a creditor refuses a debtor's deinand to reverse an improper setoff, a court would be justified in imposing the combined loss-of-security and loss-of-debt sanction. ${ }^{219}$ Although it is unclear what prompted the court to make this completely unforeshadowed statement, it is possible that the court was concerned with the possibility that if tempted with a large enough setoff, a bank may prefer to execute the setoff and obtain an unsecured personal judgment for the remaimder of the debt rather than to preserve its security interest. ${ }^{220}$ The proposed remedy would address such an intentional

the opportunity to assert the one-action rule affirmative defense to prevent unencumbered assets from being seized prior to exhaustion of all security.

215. Wozab, 51 Cal. 3d at 1001 n.8, 800 P.2d at 563 n.8, 275 Cal. Rptr. at $207 \mathrm{n} .8$ (When a bank inadvertently sets off a debtor's unencumbered bank account, but promptly returns the funds, "[a] sufficient remedy might be to hold the bank responsible for any compensatory damages suffered by the depositor."); see also Bank of Am. v. Daily, 152 Cal. App. 3d 767, 772, 199 Cal. Rptr. 557, 559 (1984) ("Arguably the fairest sanction is to require the bank to refund to the Dailys the money taken from their checking account plus accrued interest as a condition to proceeding with the judicial foreclosure.").

216. See supra text acconpanying and following notes 186-90.

217. In iniposing sanctions for the violation of $\S 726$, the courts have not been concerned with whether the creditor made a mistake or misunderstood the application of the one-action rule. See, eg., Walker v. Community Bank, 10 Cal. 3d 729, 732, 518 P.2d 329, 330-31, 111 Cal. Rptr. 897, $898-99$ (1974) (inadvertent omission of security); Salter v. Ulrich, 22 Cal. 2d 263, 268, 138 P.2d 7, 9 (1943) (ignorance of law). If such violations were allowed to be overlooked on the basis of mistake or misunderstanding, $\S 726$ cases would be rare indeed.

218. Furthermore, imposing the uniformly applicable sanction proposed by this Conunent would have a ninor impact on cases involving inadvertent setoffs because the banking industry has already been put on notice by Daily and Wozab that such an error can be extreniely costly. Presunably, banks are taking every necessary precaution to avoid inadvertent setoffs. See Wozab, 51 Cal. 3d at 1015-16, 800 P.2d at 573, $275 \mathrm{Cal}$. Rptr. at 217 (Broussard, J., concurring and dissenting) ("[I]t is reasonable to conclude that as a general rule banks are well aware that when a debt is secured by real property they are required to exhaust the security before resorting to any nonsecured property of the debtor . .. and that, under the threat of a potentially harsh sanction, they have suceessfully established proeedures to comply with this rule.").

219. Id. at 1006,800 P.2d at 566, 275 Cal. Rptr. at 210.

220. Ironically, this strategy would only have been possible under the nuajority's erroneous 
violation of section 726 by allowing the debtor to include a claim for punitive damages in its action for recovery of the setoff. ${ }^{221}$

\section{CONCLUSION}

The one-action rule is at the very heart of California's statutory antideficiency scheme. ${ }^{222}$ Despite the virtual omnipresence of the oneaction rule in California real estate litigation, the effect of its application is frequently misunderstood. As a result, the scope of the sanction for violation of the one-action rule has beconie an issue of heated debate. Analysis of relevant cases fron the past century and commentary addressimg the controversy leads to the conclusion that, under the modern inajority view, the sanction for violation of the one-action rule should be loss of any unforeclosed-on security and loss of that portion of the debt not reduced to judgment by the creditor's one action.

In Security Pacific National Bank v. Wozab the Supreme Court of California turned up its collective nose at the nodern majority view in the context of a banker's setoff executed in violation of the security-first principie of the one-action rule. By suggesting that the debtor's remedy should vary depending on whether the setoff was intentional or not and whether it was returned proinptly or not at all, the court raised more problems than it solved. In light of the Wozab decision, what is needed is a uniformly applicable remedy for all improper banker's setoff cases. The proposed reniedy-requiring return of the funds set off, awarding conipensatory and perhaps punitive damages, and providing the debtor with the option either to raise the one-action rule affirmative defense or to be excused from hability on the security interest-addresses the shortcomings of the Wozab opinion by providing the courts with a single uniformly applicable remedy that is not an overtly punitive measure, that recognizes the seriousness of an iniproper setoff, and that is grounded in one-action rule doctrine.

belief that a suit for conversion of funds, in addition to a suit for violation of $\S 726$, would not lie. This is clearly not the case. See supra note 208 and accompanying text.

221. Stillman, supra note 12 , at 10.

222. Hetland \& Hansen, supra note 6, at 195 ("Section 726 is the linchpin of the entire system; it is the statute which, both in its text and its decisional exegesis, most fully and vividly reflects the fundamental policy concerns and choices of the real property system."). 